\title{
ACHIEVING QUALITY AND RESPONDING TO CONSUMERS THE Medicare BeneFICIARY COMPLAINT PROCESS: WHO SHOULD RESPOND?*
}

\author{
Diane E. Hoffmann, J.D., M.S.** \\ \& Virginia Rowthorn, J.D."*
}

\section{TABLE OF CONTENTS}

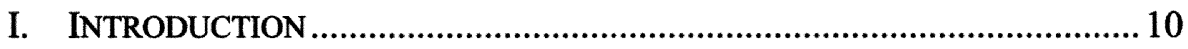

II. THE QIO COMPLAINT PROCESS ........................................................ 13

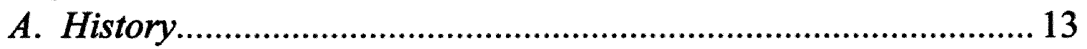

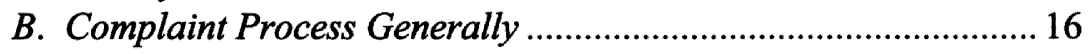

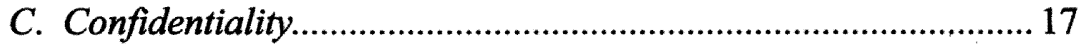

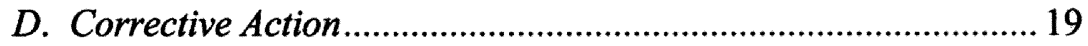

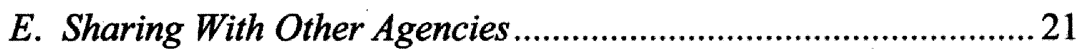

F. Number of Complaints Handled by QIOs ................................... 22

III. CONCERNS ABOUT THE CURRENT QIO SYSTEM ......................................23

IV. ALTERNATIVE TO QIOS FOR RESPONDING TO BENEFICIARY

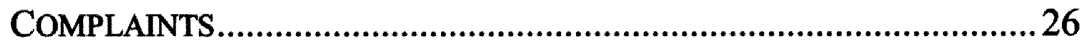

A. State Survey Agencies.................................................................... 28

* An earlier version of this paper was prepared at the request of the Center for Medicare Advocacy and presented on January 19, 2007, at a daylong working conference entitled Beyond QIO: Modeling a Medicare Beneficiary Complaint Process for Quality of Care. Fortytwo health policy experts attended the meeting, including beneficiary advocates, professors of law and public policy, attorneys, physicians, policy researchers, industry representatives, government officials, Congressional staff members, and representatives of various agencies that handle Medicare beneficiary complaints, to develop an alternative structure for responding to beneficiary complaints about quality of care. This paper formed the basis for the development of a "consensus model of an ideal Medicare beneficiary complaint review system." Additional information about the project, which was supported by a grant from the Commonwealth Fund, can be found at http://www.medicareadvocacy.org/projects_QIOconference.htm. We would like to express our special thanks to Peter Hollman, M.D., who also presented at the 2007 conference, for his invaluable comments and contributions to this paper. We would also like to thank Alfred J. Chiplin, Jr., J.D., M.Div., Managing Attorney, and Toby S. Edelman, Ed.M., J.D., Senior Policy Attorney, at the Center for Medicare Advocacy for reading our paper and providing comments and insights, many of which we incorporated into our paper. Finally, we would like to thank our student research assistants, Rebecca Jesada and Vanessa Schultz for their tireless assistance.

** Diane E. Hoffmann, Professor of Law, Director, Law \& Health Care Program, University of Maryland School of Law.

*** Virginia Rowthorn, Managing Director, Law \& Health Care Program, University of Maryland School of Law. 
1. History of Responsiveness of State Survey Agencies to Consumer Complaints ....................................................... 28

2. Characteristics of the Current Complaint Process ............... 31

B. State Medical Boards ............................................................... 37

C. Combined Entity Including State Survey Agency and State

Medical Board

1. Elements of an Alternative Complaint Entity....................... 43

2. Assessment of Alternative Complaint Entity..........................45

V. CONCLUSION.

Mary Anderson was distraught about the care her 83 year old mother was receiving at Shady Village Nursing Home. When she went there to visit her yesterday Mary discovered that her mother had a large decubitis ulcer on her back. She complained to the Nursing Home Administrator but did not think that was enough. She knew that decubitis ulcers can be prevented by good quality care. Mary did not want to sue, but she wanted to find out how this happened, who was at fault, and to make sure it did not happen again. She wondered to whom she should address her concerns - the nursing home ombudsman? The state agency that licenses long term care facilities? Or some other entity?

\section{INTRODUCTION}

Quality improvement ("QI") has become a mantra in virtually all service industries, but perhaps more so in health care. In part, QI can be informed by consumer and patient complaints. Ideally there is a feedback loop linking complaint information to those responsible for quality improvement. Yet responsiveness to complainants and quality improvement efforts can sometimes be at odds or at least create tensions. Such tensions arise between, among other things, the joint goals of: confidentiality of provider information and transparency in explaining what happened to patients; provider autonomy and quality improvements that require across the board adherence to standards with little flexibility; due process in investigating complaints and providing patients with timely responses to their inquiries; and between a private mediated resolution and public sanctions to deter similar behavior by others. These tensions are playing out in a debate between Medicare beneficiary advocates, the Centers for Medicare and Medicaid Services ("CMS"), and the Quality Improvement Organizations ("QIOs") that are currently responsible for responding to beneficiary complaints about poor quality health care. That debate is the motivation for this paper, which examines what type of entity is most appropriate to respond to complaints by Medicare beneficiaries regarding the quality of care they receive. 
In its relatively short history, the Medicare beneficiary complaint process that currently rests within the nation's QIOs has been the subject of three major reports - two by the Department of Health and Human Services' ("DHHS") Office of the Inspector General ("OIG") and one by the Institute of Medicine ("IOM"). The first of those reports focused on how the process could be improved while remaining within the QIO program. 'The second report recommended that CMS either make major improvements to the current process within the QIOs or establish a complaint process outside of the QIO program. ${ }^{2}$ The final and most recent report made a single recommendation regarding the complaint process - " $\mathrm{t}] \mathrm{he}$ QIO in each state should no longer have responsibility for handling beneficiary complaints, appeals, and other case reviews for payment or other purposes."3 As support for taking the complaint process out of the QIO program has increased, various suggestions have been made regarding a new "home" for this important function. The second report, prepared by the OIG, suggested establishing a new program or contract mechanism within CMS or, alternatively, building on "existing entities that already conduct similar work, such as State survey and certification agencies, State medical licensure boards, and the State Health Insurance Partnership Program."4 The most recent report, prepared by the IOM, recommended that CMS consolidate the beneficiary complaint and review functions "into a few regional or national competitive contracts" or, alternatively, "determine the most appropriate agencies with which to contract for [this] purpose in each state." Among those agencies, the report suggested "state health departments and the state [s] urvey and [c]ertification agencies."

The Medicare advocacy community has also made efforts over the last several years to raise awareness of deficiencies in the QIO beneficiary complaint process. The Coalition for Consumer and Quality in Health Care Reform, the Center for Health Care Rights, the National Senior Citizens Law Center, the Center for Medicare Advocacy ("CMA"), the Citizen Advocacy Center ("CAC"), and AARP provided official comments on the 1995 OIG Report. ${ }^{7}$ AARP and CAC provided official comments on the 2001 OIG report. $^{8}$ Most recently, in January 2007, the CMA held a day long working conference

1. See DHHS OfFICE OF INSPector Gen., PUB'N No. OEI-01-93-00250, The Beneficiary Complaint Process of the Medicare Peer Review Organizations (1995), http://oig.hhs.gov/oei/reports/oei-01-93-00250.pdf [hereinafter 1995 OIG REPORT].

2. See DHHS OFFICE OF INSPECTOR GEN., PUB'N No. OEI-01-00-00060, THE MEDICARE BENEFICIARY COMPLAINT PROCESS: A RUSTY SAFETY VALVE (2001), http://oig.hhs.gov/oei/ reports/oei-01-00-00060.pdf [hereinafter 2001 OIG REPORT].

3. InSt. OF MED., Medicare's QUality Improvement ORganization Program: MAXIMIZING Potential 112 (National Academic Press 2006) [hereinafter 2006 IOM REPORT].

4. 2001 OIG REPORT, supra note 2, at iii.

5. 2006 IOM REPORT, supra note 3, at 112.

6. See 2006 IOM REPORT, supra note 3 , at 115.

7. 1995 OIG REPORT, supra note 1, at 36-49.

8. 2001 OIG REPORT, supra note 2, at 32-45. 
for which an earlier version of this paper was commissioned, on alternative structures for the Medicare beneficiary complaint process. ${ }^{9}$

The most recent push for reform of the QIO beneficiary complaint process has come from Congress. On August 2, 2007, United States Senators Charles Grassley and Max Baucus introduced Senate Bill 1947, the "Continuing the Advancement of Quality Improvement Act of 2007." The bill requires a major overhaul of the QIO program and would strip the beneficiary complaint function from the QIOs and place it with new "Medicare Provider Review Organizations." advocacy community, ${ }^{11}$ awaits action by the Senate Finance Committee. More recently, two bills were introduced in both houses that would, among other things, make changes to the QIO program's beneficiary complaint process but leave the review process with the QIOs. Senate Bill 2396 was filed on November 16, 2007, by Senators Orrin Hatch, John Rockefeller, Trent Lott, and Edward Kennedy. Section 2 of the bill requires that beneficiaries be informed of the results of complaints they file about quality of care matters and what actions were taken as a result of the complaint. The bill was referred to the Senate Finance Committee. The same language is included in House of Representatives Bill 1046, filed on February 14, 2007, by Congressman Michael Burgess, a member of the House Energy and Commerce Committee, Subcommittee on Health, the committee to which the bill was referred upon introduction. No further action has been taken on any of these legislative proposals.

While there is considerable merit to removing the complaint process from the QIOs entirely and creating a new entity to handle such complaints, this solution could result in a duplication of effort between the new entity and existing state and federal entities in the area of complaint investigation. This Article is designed to add to the debate about the most appropriate home for the beneficiary complaint process by evaluating an alternative to the QIO complaint structure based on existing entities that already conduct similar work. First, the Article examines the current QIO process, including its history and structure, as well as some of the specific areas that have been the subject of particular scrutiny over the years, i.e., confidentiality of provider information, corrective action, sharing with other agencies, and the number of complaints handled annually by QIOs. The Article then sets forth the criticisms of the QIO program as identified in several studies, criteria for evaluating alternatives to QIOs, and an alternative to QIOs for responding to beneficiary complaints that incorporates state survey agencies and state medical boards. This alternative takes advantage of already existing expertise in the area of complaint resolution;

9. See asterisk, supra prior to note 1 .

10. Continuing the Advancement of Quality Improvement Act of 2007, S. 1947, 110th Cong. (2007).

11. See Center for Medicare Advocacy Praises the "Continuing the Advancement of Quality Improvement Act of 2007," MED. NEws TODAY, Aug. 16, 2007, http://www.medical newstoday.com/articles/79723.php (last visited Jul. 13, 2007). 
however, the alternative is not put forth as a recommendation but rather as a springboard for examining the next steps that might be taken to improve the Medicare beneficiary complaint process. ${ }^{12}$

\section{ThE QIO COMPLAINT PROCESS}

\section{A. History}

The QIO Program (formerly referred to as the Medicare Utilization and Quality Control Peer Review Organization or "PRO" Program) was created by statute in 1982. ${ }^{13}$ The QIO program is "the federal government's primary tool for assuring that services provided to Medicare beneficiaries are medically necessary, of a quality that meets professionally recognized standards of health care, and provided in an appropriate setting." proximately $\$ 400$ million a year on the program's forty-one contractors, which covers all fifty states and Washington D.C., Puerto Rico, and the Virgin Islands. ${ }^{15}$ In addition to other quality improvement activities, QIOs have been required since 1986 to review and investigate all written complaints received from Medicare beneficiaries about the quality of Medicare-covered services received in Medicare-certified facilities. ${ }^{16}$

The work of the QIOs is governed by three-year contracts drafted to conform to a "Statement of Work" ("SOW") that is produced by CMS. ${ }^{17}$ The QIOs will operate under the eighth SOW until July 31, 2008. ${ }^{18}$ During the first three SOW contracts, the focus of the QIO program was to ensure the necessity, quality, and appropriateness of care rendered to Medicare beneficiaries by identifying individual clinical problems through random medical record review. Since 1993, when the fourth SOW contracts took effect, QIOs have aimed to improve the overall practice of medicine by analyzing patterns of care and out-

12. Our research for this paper included a review of the available literature and government documents, interviews with two Directors and one former Director of State Survey Agencies, a representative from the Federation of State Medical Boards, as well as conversations with a Director of a State Medical Board, a QIO consultant, and staff at CMS. In addition, we received comments from the American Health Care Quality Association on an earlier draft of the paper.

13. The Peer Review Improvement Act of 1982, Pub. L. No. 97-248, sec. 143, $\$ \S 1151$ 1163, 96 Stat. 324 (1982), abolished the old Professional Standards Review Organizations and created the Peer Review Organization program, which was intended to be a leaner and more effective program than its predecessor. In 2002, PROs were renamed QIOs. See 67 Fed. Reg. 35,539 (May 24, 2002).

14. BARRY R. FurRow Et AL., HeALTH LAW § 3-24 (2d ed. 2000).

15. 2006 IOM REPORT, supra note 3 , at $63,180-81$.

16. Omnibus Budget Reconciliation Act of 1986, 42 U.S.C. $\S 1320$ c-3(a) (2000).

17. See FURROW ET AL., supra note 14, § 3-24.

18. The eighth SOW began on August 1,2005 and runs through July 31,2008 . See 8th Round SOW Contract 148 (2005), http://www.cms.hhs.gov/QualityImprovementOrgs/ downloads/8thSOW.pdf. 
comes and by sharing information with the medical community. This more recent emphasis on patient care and outcomes was initiated in response to recommendations made in a 1990 IOM report which assessed Medicare quality assurance efforts. ${ }^{19}$ Under this newer approach, random sample record reviews were phased out and CMS, at the initiation of the fourth SOW, emphasized the importance of the beneficiary complaint process in carrying out the work of the QIO program.

In a 1994 statement describing its vision of a successful PRO five years down the road, CMS suggested that these organizations "will have earned a position of trust in the eyes of plans, providers, and practitioners and beneficiaries" and that this public trust will be "based on responsive investigation of complaints and protection of consumers."20 This view was echoed in a 1995 report issued by the OIG entitled The Beneficiary Complaint Process of the Medicare Peer Review Organizations ("1995 OIG Report"). ${ }^{21}$ In that report, the authors noted that, as medical record review declines, "the [QIO] process for receiving and investigating complaints from Medicare beneficiaries takes on added significance. It becomes a major vehicle through which the [QIOs] can identify and respond to individual instances of poor medical care. It is vital, therefore, that the complaint process be functioning well."22

The manner in which QIOs handle complaints has evolved with each successive SOW and the significance of this function has increased in response to a number of critical reports. ${ }^{23}$ A 2001 OIG report entitled The Medicare Beneficiary Complaint Process: A Rusty Safety Valve ("2001 OIG Report") ${ }^{24}$ found that, at least through the sixth SOW (1999-2002), beneficiary complaints were treated as a "distinctly minor activity" by CMS and therefore by the QIOs. ${ }^{25}$ In that sixth SOW, the complaint process fell under "Other Contract Activities." This catch-all section represented eighteen percent of the estimated QIO budget. $^{26}$

In response to the 2001 OIG Report, the role of the beneficiary complaint process was reevaluated and, in the seventh and eighth SOW contracts, beneficiary complaint resolution was included in "Medicare Beneficiary Protection Activities." An estimated $\$ 45.5$ million dollars (or $5.8 \%$ of the core contract) was allocated to these "Protection Activities" in the seventh SOW. ${ }^{27}$ In addi-

19. See Medicare: A STRATEgY For QUALITY Assurance, Vol. 2 (Kathleen N. Lohr ed., The Nat'l Acad. Press 1990).

20. 1995 OIG REPORT, supra note 1, at 2 \& F-2 n.7.

21. See 1995 OIG REPORT, supra note 1.

22. Id. at i.

23. See discussion infra. See also 1995 OIG REPORT, supra note 1; 2001 OIG REPORT, supra note 2; 2006 IOM REPORT, supra note 3.

24. See 2001 OIG REPORT, supra note 2.

25. Id. at 14 .

26. Id.

27. See 2006 IOM REPORT, supra note 3 , at 181 tbl.7.7. The IOM report noted that these "[c]alculations are approximate and were done by the IOM committee on the basis of CMS data." Id. The IOM report also noted that the total estimated budget for the seventh SOW was 
tion to upgrading the importance of the complaint process in the SOW, CMS modified the process to "be more service-oriented and responsive to beneficiaries" ${ }^{28}$ by adopting a case manager approach, revising "Response Determination Categories" and subsequent actions to be taken upon a determination offering a satisfaction survey to beneficiaries, and offering mediation as an alternative to the medical record review process. ${ }^{29}$

Following a six-state pilot project conducted in $1998-99,{ }^{30}$ the use of mediation as an alternative to case review for resolution of beneficiary complaints was implemented throughout the entire QIO system in September 2003, ${ }^{31}$ but the option has met with mixed results. The 2006 IOM study, entitled Medicare's Quality Improvement Organization Program: Maximizing Potential ("2006 IOM Report"), found that, as of July 2004, only fifteen states had completed at least one mediation under this new option. ${ }^{32}$ According to a CMS official, while mediation is currently offered by every QIO, it has not taken off as a remedy because it is only available in a small subset of complaints ${ }^{33}$ and not all QIOs are making the same effort to promote mediation. ${ }^{34}$ Although CMS and the QIOs believe that mediation has improved beneficiary satisfaction, they also have found it to be labor intensive. ${ }^{35}$ Therefore, CMS has sought addi-

$\$ 1,154.3$ million, of which $\$ 796.7$ million supported core contract activities and \$357.6 million covered support contracts and special studies. Id. at 180 tbl.7.5. The report further noted that, "[a]s of May 31, 2005, the total apportionment for the 8th SOW was slated at $\$ 1,265$ billion, a nine percent increase over that for the 7th SOW." Id. at 179.

28. CTRS. For MEDICARE \& MEDICAID SERV., MEDIATION: A NEW OPTION FOR MEDICARE BENEFICIARIES TO RESOLVE COMPLAINTS FILED THROUGH QIO 1(2004), http://www.cms.hhs.gov /BeneComplaintRespProg/Downloads/3a.pdf [hereinafter CMS, MEDIATION].

29. Id.

30. See Press Release, Lumetra, Mediation Becomes Option to Resolve Medicare Benefi-

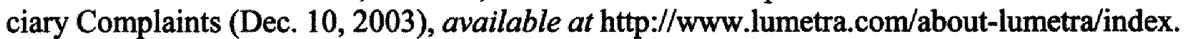
aspx?rpID1=46\&id=129. See also 2006 IOM REPORT, supra note 3, at 308; 2001 OIG REPORT, supra note 2, at $2 \& 49$ n.5 (citing The California Medical Review Incorporated [now Lumetra], in collaboration with the University of California at San Francisco, RAND Corporation, and Center for Social Redesign, The Medicare Beneficiary Complaint Alternative Methods Study, 500-96-P535, Modification P00014 (Oct. 1999)).

31. See David G. Schulke, Am. Health Quality Ass'N, Medicare Beneficiary COMPlaint Process - QIOS aNd Possible Alternatives: COMMENTS AND SugGestions 2 (2007), http://www.medicareadvocacy.org/QIOConference/SubstantiveInfo/AHQAResponseTo LLegalBGPaper.pdf [hereinafter QIO Comments].

32. See 2006 IOM REPORT, supra note 3, at 319. "[I]n July 2004, CMS released an RFP for competitive special study PXX401 entitled 'Beneficiary Protection Program Activities Alternatives to Traditional Case Review in Beneficiary Complaints' via SDPS Memorandum 04304-CO." QIO Comments, supra note 31, at 2.

33. CMS divides quality complaints into cases where "No Substantial Improvement Opportunities are Identified" or "Care Could Have Been Better." Where "Care Could Have Been Better," the cases fall into one of three groups: "1) Care Was Grossly and Flagrantly Unacceptable; 2) Care Failed to Follow Accepted Guidelines or Usual Practice; 3) Care Could Reasonably Have Been Expected to be Better." CMS considers cases falling into groups 1 or 2 "not suitable" for mediation. CMS, MEDIATION, supra note 28, at 2.

34. Telephone Interview with Commander Sheila C. Blackstock, Director, Division of Quality Improvement Program Policy for Acute Care Quality Improvement Group, OCSQ, CMS, in Baltimore, MD. (Nov. 22, 2006).

35. QIO Comments, supra note 31 , at 2. 
tional alternatives to case review. CMS funded a study by New York's QIO to test "Alternative Approach Improvement Methodology," a QIO-facilitated method of alternative dispute resolution. Methods developed under this study were incorporated into the eighth SOW. ${ }^{36}$

\section{B. Complaint Process Generally}

The scope of review of beneficiary complaints is set forth in the QIO Manual published online by CMS. In order for a QIO to handle a complaint, the complaint must: 1) pertain to a service covered by Medicare regardless of whether the service was covered for the particular beneficiary making the complaint or whether Medicare payment was made on behalf of that beneficiary; 2) relate to a service furnished by a health care practitioner, or an institution or non-institutional provider who, at the time of the service, was qualified to have payment made to them; 3 ) relate to a service furnished while the complainant was a Medicare beneficiary; and 4) be in writing. ${ }^{37}$

The QIO Manual outlines the basic roadmap for a QIO responding to a complaint. QIOs are to:

- Acknowledge Receipt of the Complaint

- Request Medical Records

- Receive Medical Records

- Complete Quality Review

- Determine whether the quality of services met professionally recognized standards of health care.

- If no potential quality concern is identified during retrospective review, complete review and send a written determination to the involved providers/practitioners.

- If a potential quality concern is identified, provide notice to the provider/practitioner to discuss and/or provide a response to the potential concern. Complete review and send a written determination to the provider/ practitioner involved.

36. Id. at 3 .

37. See CTRS. FOR MEDICARE \& MEDICAID SERVS., QUALITY IMPROVEMENT ORG. MANUAL ch. 5, § 5005 (2003), http://www.cms.hhs.gov/manuals/downloads/qio110c05.pdf [hereinafter CMS, QIO MANUAL]. If a beneficiary attempts to make an oral complaint, the QIO Manual states that assistance should be provided to help the beneficiary make the complaint in writing. Id. $\S 5010$. 
- If a potential quality concern is confirmed, give the provider/practitioner notice of the QIO's final determination, including their right to request a rereview of the determination.

- Provide an opportunity for the provider/practitioner to consent to or prohibit the disclosure of information that explicitly or implicitly identifies that practitioner.

- Respond to Complainant

- Take Corrective Action

- Require quality improvement plans (such as safety measure initiatives/preventive measures).

○ Recommend OIG sanction. ${ }^{38}$

\section{Confidentiality}

The issue of confidentiality has been the Achilles heel of the complaint process since the first critical OIG report in 1995. Specifically, QIOs have been criticized for responding inadequately to complainants by allowing practitioners to prohibit disclosure of information that explicitly or implicitly identifies them. The result of this prohibition was that QIO response letters to complainants were extremely vague - not even indicating if substandard care had been found. The 2001 OIG Report asserted that QIOs have a difficult time obtaining physician consent, particularly when the medical record review substantiates a quality of care concern. According to that report, QIOs obtain consent in just twenty-one percent of complaint reviews where such a concern is identified (and forty-two percent where no such concern is identified). ${ }^{39}$

The disclosure prohibition within the complaint process is grounded in the Peer Review Improvement Act $^{40}$ ("Peer Review Act") and the implementing CMS regulations. Under the statute, any data or information acquired by the QIO must not be disclosed except: 1) to the extent necessary to carry out the goals of the legislation; 2) by regulations that must be designed to assure protection of the rights of patients and practitioners; and 3) to certain federal or state agencies. ${ }^{41}$ Based on this statutory framework, CMS promulgated regulations defining "confidential information" as, among other things, "information that explicitly or implicitly identifies an individual patient, practitioner or re-

38. Id. $\S \S 5005-5040$.

39. See 2001 OIG REPORT, supra note 2 , at 11.

40. Peer Review Improvement Act of 1982, Pub. L. No. 97-248, §§ 141-150, 96 Stat. 381 (codified as amended at 42 U.S.C. $\S \S 1320 \mathrm{c}-1320 \mathrm{c} 12$ ).

41. 42 U.S.C. $\S 1320 c-9$ (a) (2000). 
viewer., ${ }^{42}$ The administrative history of the regulations indicates that the agency believed general disclosure of confidential information would be inappropriate, because "the potential is great [that] such information [would] be misinterpreted and misused." ${ }^{, 43}$ CMS further felt that general disclosure of identifying information could "reduce the effectiveness of the peer review process." 44

The confidentiality issue is muddied somewhat by another provision of the Peer Review Act, requiring QIOs to inform beneficiaries of the final disposition of a complaint. ${ }^{45}$ Balancing these two mandates was the subject of a federal district court case in 2001, in which the nonprofit organization Public Citizen sued CMS alleging that the regulations which prohibited disclosure by a QIO of the final disposition of a complaint investigation were at odds with the Peer Review Act. ${ }^{46}$ In that case, the petitioner, on behalf of a widower who complained to a QIO about the treatment his late wife received, argued that the confidentiality requirements were incompatible with the statutory requirement that the QIO "inform the individual (or representative) of the organization's final disposition of the complaint." ${ }^{, 47}$ The Court of Appeals for the District of Columbia affirmed the lower court's decision that the term "final disposition" requires a QIO to inform complainants of the substantive (rather than procedural) disposition of the complaint. In a somewhat ambiguous holding, the court held that "the statutory command to inform a complainant of the 'final disposition' of the complaint requires more than what [CMS] currently permits. At a minimum, it requires the organization to notify the complainant of the results of its review." tion as to whether the quality of the services that the recipient received met 'professionally recognized standards of health care." "49 The court would not go as far as to require a QIO to reveal to a complainant what corrective action it took in response to the complaint but stated that doing so "represents a reasonable elaboration of the meaning of the term [final disposition]." ${ }^{50}$ As a result of this case, letters to complainants now reveal more information than before, but the essential problem of disclosure of practitioner-identifying information remains. QIOs are still prohibited from disclosing such information without con-

42. 42 C.F.R. $\S 480.101$ (b) (2006).

43. 50 Fed. Reg. 15,347-01, 15,355 (Apr. 17, 1985) (setting forth the final rule for 42 C.F.R. pts. 400 and 476 ).

44. Id.

45. The Omnibus Budget Reconciliation Act of 1986, Pub. L. No. 99-509, Sec. 9352 , 100 Stat. 1874, 2047 (codified as amended at 42 U.S.C. $§ 1320 c-3(a)(14)(2000)$ ) added this section.

46. Public Citizen, Inc. v. Dep't of Health \& Human Servs., 332 F.3d 654 (D.C. Cir. 2003), aff'd, 151 F. Supp. 2 d 64 (D.D.C. 2001).

47. Id. at 657 (citing 42 U.S.C. $\S 1320 \mathrm{c}-3(\mathrm{a})(14)(2000)$ ).

48. Id. at 656 .

49. Id. at 671 (quoting 42 U.S.C. § 1320c-3(a)(14) (2000)).

50. Id. 
sent $^{51}$ and are therefore limited in the information they can provide to complainants.

CMS has attempted unsuccessfully to address this issue of confidentiality. In response to the 1995 OIG Report, CMS worked on revising the confidentiality regulations, but reported that it was unable to publish a final rule. ${ }^{52}$ In his response to the 2006 IOM report, Secretary of the Department of Health and Human Services, Michael Leavitt, again addressed the issue and stated that "in addition to the current beneficiary complaint work, CMS is determining how it can permit the disclosure of information from complaint review to beneficiaries and restrict redisclosure of this information and its use in liability actions."53

In the view of the authors of the 2006 IOM Report, the "QIO confidentiality restrictions are not necessary or supportable in the current era of public reporting and are incompatible with the aim of a national performance measurement system and the goal of CMS to serve multiple audiences with a transparent system." tion gives the Secretary of DHHS the authority to set confidentiality standards by regulation, new legislation for this purpose is not necessary" and may therefore be modified by the Secretary to increase the transparency and responsiveness of the QIOs. ${ }^{55}$

\section{Corrective Action}

It is clear from the QIO Manual that corrective actions on the part of a QIO following a substantiated complaint investigation, while permitted, are not considered an integral part of the complaint process. The 2001 OIG Report found that QIOs "rarely take any action beyond a notification letter to providers

51. See CMS, QIO MANUAL, supra note $37, \S 5020, \S 5025$, \& exh.5-17 (Final Response to Inquirer Model Notice (Concern Involved Practitioner)). The model final response letter in a case in which the involved practitioner does not consent to disclosure states:

We have carefully examined your concern(s) and conducted a thorough review of the medical records pertaining to the services that (you or name of beneficiary) received. Federal regulations prohibit us from releasing information that identifies the involved practitioner without his or her consent. Because the involved practitioner did not give (his or her) consent, we are unable to release information that would explicitly or implicitly identify $\mathrm{him} / \mathrm{her}$. This does not necessarily mean that we found a problem with the services (you or name of beneficiary) received. However, we will take appropriate action if warranted by our review findings.

Id. exh.5-17.

52. See 2001 OIG REPORT, supra note 2, at i.

53. Michael O. Leavitt, SeC'y of Health \& Human Services, Rep. to Cong.: IMPROVING THE MEDICARE QUALITY IMPROVEMENT ORGANIZATION PROGRAM-RESPONSE TO THE $\begin{array}{lllll}\text { INSTITUTE OF } & \text { MEDICINE } & \text { STUDY } & \end{array}$ http://www.cms.hhs.gov/QualityImprovementOrgs/down loads/QIO_Improvement_RTC_fnl.pdf.

54. See 2006 IOM REPORT, supra note 3, at 125.

55. Id. 
and practitioners in response to confirmed quality concerns based on complaints." The same report found "no examples of a [QIO] calling for remedial training, coursework, or special supervision."57 The report also found that "more serious interventions, such as referring a physician to the State medical board ... were even rarer." 58 Only nine of the fifty QIOs that responded to the survey undertaken in that study "reported making such a referral at least once during their fifth [SOW]" (a period of three years). ${ }^{59}$ Likewise, the study found that QIO referrals to state survey agencies are uncommon, finding that only "six [QIO]s reported making such referrals for confirmed concerns during their fifth [SOW].",60

The QIO Manual offers the following non-directive advice regarding corrective actions a QIO may undertake:

You may engage in a variety of activities, including the development of corrective action plans, to improve care rendered by providers/involved practitioners when quality concerns are identified. ... You may consider coordinating efforts with other entities such as intermediaries, carriers, State Agencies, CMS Regional Offices, . . . OIG, or State licensing/certification boards to effectuate corrective action .... Y You may also consider initiating improvement projects, when appropriate/feasible. ${ }^{61}$

Under statute, a QIO may initiate sanction proceedings by referring case information and sanction recommendations to the OIG. ${ }^{62}$ The QIO Manual instructs QIOs to initiate sanction procedures when they "identify failure by a practitioner in a substantial number of cases to comply with his/her obligations and/or a gross and flagrant violation as specified in section 1156(b) of the Act and 42 CFR 1004.1(b) ...."63 In a critical 2005 news article, Gilbert M. Gaul of the Washington Post reported that, "from 1986 to 1994, QIOs recommended 278 sanctions against all providers, mostly doctors. From 1995 to 2003, they recommended 12 sanctions, according to the inspector general's office. In four of the nine years, there were none at all."64 Gaul concluded that this downward

56. See 2001 OIG REPORT, supra note 2, at 9.

57. Id.

58. Id. at 10 .

59. Id.

60. Id.

61. See CMS, QIO MANUAL, supra note $37, \S 5040$.

62. 42 U.S.C. $\$ 1320$ c-5(b)-(c) (2000); 42 C.F.R. $\$ 1004.70$ (2006).

63. See CMS, QIO MANUAL, supra note $37, \S 5040$.

64. Gilbert M. Gaul, Once Health Regulators, Now Partners: Private Groups Limit Patient Access to Medical Files, Rarely Punish Doctors, WASHINGTON POST, July 26, 2005, at A1. 
trend is related to the current QIO emphasis on collaborating with providers. ${ }^{65}$ The authors of the 2006 IOM Report believe that this drop in sanction recommendations is not likely to change given that, under the current SOW, QIO evaluations (by CMS) will be tied to hospital satisfaction ratings to a greater degree than under previous SOWs. ${ }^{66}$

\section{E. Sharing With Other Agencies}

One might argue that QIOs need not sanction health care providers for poor quality care as that is already done by state survey and certification agencies and state medical boards. Yet, these state agencies and boards must know about provider infractions or complaints before they can respond to them. Consequently, one might expect the agencies to share information, but this does not happen on a routine basis.

No formal relationship, for example, exists between state medical boards and QIOs. In nonbinding language, the QIO Manual suggests that QIOs "[p]articipate in the overall beneficiary complaint network with other entities" and "[a]dvise these groups of [the QIO's] role and responsibility in investigating beneficiary complaints, and solicit information regarding their role and responsibility."68

According to a 2006 DHHS study entitled State Discipline of Physicians ("2006 DHHS Board Study"), most state medical boards do not seek information from QIOs and "only a few Boards in 2003 had formal information sharing agreements with QIOs." 69

Currently, QIOs are not required to report individual practitioners to the appropriate state medical boards for purposes of investigation or discipline. The only entity to which the QIOs are required to report individual physicians is the OIG but, as mentioned earlier, only in the case of repeated or gross violations of duty. ${ }^{70}$ According to QIO regulations, "[a] QIO must disclose confi-

65. Id. However, according to the American Health Care Quality Association (AHCQA), the decrease in the number of providers referred to the OIG for sanctions is related to the significant decline in retrospective record review activity undertaken by QIOs since the fifth SOW (under which random record reviews were phased out). See QIO Comments, supra note 31, at 5-6.

66. See 2006 IOM REPORT, supra note 3, at 113.

67. See CMS, QIO MANUAL, supra note $37, \S 5045$.

68. Id.

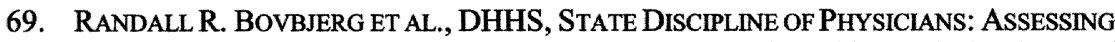
STATE MEDICAL BOARDS THROUGH CASE STUDIES 34 (2006), http://aspe.hhs.gov/daltcp/reports/ 2006/stdiscp.pdf [hereinafter 2006 DHHS BOARD STUDY] (citing FEDERATION OF STATE MEDICAL BOARDS, EXCHANGE: LICENSING BOARDS, STRUCTURE AND DISCIPLINARY FUNCTIONS tbl.29 (2003)). Only twelve Boards reported having formal agreements with QIOs and twelve more reported receiving assistance from QIOs on an occasional basis. Id. at $80 \mathrm{n} .47$.

70. In comments made on the initial draft of this paper, AHCQA stated that under CMS guidance immediate reporting to a licensing authority "should occur" in the case of grossly or flagrantly unacceptable care or immediate harm to a patient. See QIO Comments, supra note 31, at 6-7 (emphasis added). However, the guidance to which AHCQA refers is arguably op- 
dential information upon request, to State or Federal licensing bodies responsible for the professional licensure of a practitioner . . ."71 The regulation further states that "a QIO may provide the [confidential] information . . . to the State or Federal licensing body without request."72 In egregious cases, additional CMS guidance provides that QIOs must report complaints to the appropriate licensing board. ${ }^{73}$ We were unable to find information as to how often QIOs report offending physicians to state medical boards, however, when extrapolating from the number of physicians that QIOs report to the $\mathrm{OIG},{ }^{74}$ the incidence is presumably quite low.

The QIO Manual also states that QIOs may "consider coordinating efforts with other entities such as intermediaries, carriers, State Agencies, CMS Regional Offices, Office of the Inspector General, or State licensing/certification boards to effectuate corrective action ....,"75 Any such efforts must conform to disclosure requirements, which are consistent with the QIOs' overall confidentiality policy: only fraudulent actions or actions involving imminent danger to individuals can be reported to state agencies without first notifying the provider of the disclosure to the state. ${ }^{76}$ Based on interviews with state survey agency directors, many state agencies are unaware that QIOs respond to beneficiary complaints. One state survey agency director with whom we spoke commented that there are potential dangers to having parallel state complaint processes that do not communicate with each other, the most important being the possibility of a dangerous situation existing without the state survey agency being aware of it.

\section{F. Number of Complaints Handled by QIOs}

QIOs are required to report beneficiary complaint information in their annual reports, which must be posted on individual QIO websites. We researched the websites of all fifty-three QIOs in December 2006. At that time, forty-five out of fifty-three QIOs had their annual reports available online, although many did not have the most recent report online. Judging from the number of complaints reported by QIOs on their websites, the greatest number of complaints received by a QIO in a single fiscal year was 306 in California in fiscal year $2005 .^{77}$ This is the equivalent of 0.71 complaints per 10,000 Part A Medicare beneficiaries in California. At the time of our review, eight of the QIOs re-

tional.

71. 42 C.F.R. $\S 480.138(a)(1)(i)$ (2006) (emphasis added).

72. Id. at (a)(1)(ii) (emphasis added).

73. See QIO Comments, supra note 31, at 6-7.

74. See supra note 64.

75. See CMS, QIO MANUAL, supra note $37, \S 5040$.

76. See 42 C.F.R. $\$ 480.105(b)(2)$ (2006).

77. See Lumetra, California Annual Medical Services Review Report: Time Frame 11/1/2004-10/31/2005, http://www.lumetra.com/uploadedFiles/resource-center/Docs/annual-me dical-services-review-2005.pdf. 
ported fewer than ten complaints in a single year in their most recently posted annual reports. ${ }^{78}$

The 2006 IOM Study reported that the number of complaints reviewed by QIOs nationwide is surprisingly small - approximately 3,000 during fiscal year 2004 , or about one for every 14,000 beneficiaries. ${ }^{79}$ Following the fifth SOW, CMS published a document that compiled the number and nature of complaints filed with QIOs during that SOW. In the three-year contract period, QIOs received 7,218 quality complaints, $1,407(19.5 \%)$ of which had at least one confirmed concern. ${ }^{80}$ Information about the numbers and types of complaints received by QIOs is difficult to attain. CMS requires QIOs to post annual reports online and provides them with a template to do so. However, in our opinion, the template does not set forth information in a user-friendly way and therefore makes complaint information difficult to decipher.

\section{CONCERNS ABOUT THE CURRENT QIO SYSTEM}

As previously stated, the QIO complaint process has been the source of several critical reports since $1995 .^{81}$ In March of 2006, the Institute of Medicine issued a report that recommended taking the beneficiary complaint process out of the QIOs. ${ }^{82}$ This report reviewed the QIO program as a whole and included recommendations regarding the beneficiary complaint process. The report was requested under section 109(d)(1) of the Medicare Prescription Drug, Improvement, and Modernization Act of 2003 to help the Senate Finance Committee understand how the QIO program fits within the evolving performance improvement efforts in the nation's health care system. ${ }^{83}$ In addition to these critical reports, the process was the subject of the lawsuit discussed above. $^{84}$

Although CMS made changes in response to each negative report, the criticisms have been fairly consistent over time. Such criticisms may therefore indicate that the identified problems with the complaint process are intractable systemic issues that cannot be resolved without a significant programmatic overhaul. The most consistently reported criticisms of the QIO complaint

78. The eight QIOs were in Delaware, Hawaii, Montana, Nebraska, South Dakota, Vermont, Virgin Islands, and Wyoming.

79. See 2006 IOM REPORT, supra note 3, at 113.

80. CMS Office of Clinical Standards \& Quality, Data Review Project, Peer Review Organizations (PROs), 5th Scope of Work: National Findings (4/1996-2/2000), http://provide rs.ipro.org/shared/admin_memos/medicare/200202.pdf.

81. See notes 1-3 supra and accompanying text; 1995 OIG REPORT, supra note 1;2001 OIG REPORT, supra note 2; 2006 IOM REPORT, supra note 3.

82. See 2006 IOM REPORT, supra note 3, at 112-14.

83. Id. at 1.

84. Public Citizen, Inc., 332 F.3d 654 (D.C. Cir. 2003) (aff' $d$ Public Citizen, Inc., 151 F. Supp. 2 d 64 (D.D.C. 2001)). 
process can be divided into categories of accessibility, responsiveness, effectiveness, and accountability.

In terms of accessibility, or the ease with which the complaint process can be accessed by beneficiaries, the QIOs do not score well. Both the OIG and the IOM found that Medicare beneficiaries lack awareness of the QIO complaint review function and that the process is difficult to access. ${ }^{85}$ Although there is no current information regarding the number of beneficiaries who know about the QIO complaint process, the 1995 OIG Report found that seventy-seven percent of Medicare beneficiaries were not aware of the QIOs. ${ }^{86}$ The 2006 IOM Report noted that in general, many beneficiaries may be unaware of their local QIO and more specifically, its complaint review functions, "even though the contact information for all QIOs is listed in the Medicare handbook."87 Additionally, the IOM Report noted that even if the Medicare beneficiary finds the QIO internet home page, only some QIO websites "prominently feature information on how consumers can submit complaints." 88 For example, when we reviewed the homepage of California's QIO, Lumetra, it recommended that beneficiaries call the National Medicare Hotline rather than contact the QIO directly. ${ }^{89}$ Secretary Leavitt admitted that accessibility was a problem in his 2006 response to the IOM study in which he stated: "To support needed changes in the QIOs very important complaint review activities, CMS will engage QIOs to expand outreach to beneficiaries through media, print publications, direct communications, and work with the CMS Ombudsman on developing a link on the CMS web page."

QIOs have also been consistently criticized for their lack of responsiveness to complainants, specifically that they do not respond in a meaningful way. ${ }^{91}$ In response to the court's ruling in the Public Citizen case, QIOs now provide complainants with their determination as to whether the quality of the services met professionally recognized standards of health care. However, they still do not reveal information that identifies a practitioner. This fact, coupled with the fact that the QIOs refer so few practitioners to state medical boards,

85. See 1995 OIG REPORT, supra note 1, at 5-6; 2001 OIG REPORT, supra note 2, at 7-8; 2006 IOM REPORT, supra note 3, at 113-14.

86. See 1995 OIG REPORT, supra note 1 , at 5.

87. See 2006 IOM REPORT, supra note 3, at 113.

88. Id.

89. See Lumetra, For Medicare Members, http://www.lumetra.com/resourcecenter/index.aspx?id=130 (last visited Jul. 13, 2007). QIOs are required to post this toll-free phone number on all beneficiary-targeted materials, including websites. See QIO Comments, supra note 31, at 9. However, QIOs are not required to direct all complaints to that number. In contrast to Lumetra's website, at the time of our review, the website of the Delmarva Foundation (the QIO for Maryland and the District of Columbia) had a link on its homepage informing beneficiaries how to make complaints about quality of care directly to the Delmarva Foundation. See Delmarva Foundation, Consumer Medicare Resources, http://www.delmarvafoundation.org /consumers/medicare/complaints.html (last visited Jul. 13, 2007).

90. Leavitt, supra note 53, at 23.

91. See 1995 OIG REPORT, supra note 1, at 6; 2001 OIG REPORT, supra note 2, at 11-12. 
means that the process essentially has no corrective consequences for practitioners.

QIOs have also been criticized for failing to use complaint data in a manner that helps identify patterns of poor care, despite the fact that the primary responsibility of QIOs is to encourage quality improvement in Medicare." The 2001 OIG Report found that "just [one] of 50 [QIOs] reported implementing a quality improvement project based on beneficiary complaints." ${ }^{.92}$ In this same vein, QIOs have been criticized for treating "complaints as individual incidents, rather than as potential signs of systemic problems." ${ }^{\text {"93 }}$ In terms of investigative capacity, the OIG found that QIOs do not use full Congressionally-authorized investigative authority and rarely go beyond record review when investigating a complaint. $^{94}$

Any adequate complaint system must have the ability to apply remedies or sanctions upon substantiating a complaint. QIOs have been criticized for rarely taking action beyond a letter to the provider or practitioner who was found to have provided substandard care. ${ }^{95}$ Further, as mentioned above, QIOs rarely make referrals to licensing boards ${ }^{96}$ and the number of sanctions against physicians recommended by QIOs has dropped dramatically since $1986 .{ }^{97}$

According to the 2006 IOM Report "QIO surveys of complaints revealed high levels of beneficiary satisfaction with the complaint review process but much lower levels of satisfaction with the outcomes of the reviews." reports that " $93 \%$ of complainants are now satisfied with the review process." 99 This satisfaction with the process makes sense given that, after the 1995 OIG report, CMS changed its guidelines for how long the complaint process should take, reducing "the total days allowed from 250 to 165 days and developing model letters to improve the readability of [QIO] responses to complainants."100 From the beneficiary's point of view, however, the outcome of the reviews is still unsatisfactory, according to the IOM report. ${ }^{101}$ This may well have to do with the intractable confidentiality problem. As Secretary Leavitt noted in his recent report to Congress, "[m]ost complainants want a process that helps them understand what happened, and if there is something that should not have occurred, they want to know that action has been taken to prevent future occurrences."102

92. 2001 OIG REPORT, supra note 2 , at 11.

93. Id. at 8 .

94. Id. at 8-9.

95. Id. at 9.

96. 2001 OIG REPORT, supra note 2, at 10.

97. See 2006 IOM REPORT, supra note 3, at 113.

98. Id. at 114 .

99. Leavitt, supra note 53, at 22.

100. 2001 OIG REPORT, supra note 2, at 2.

101. See 2006 IOM REPORT, supra note 3, at 114.

102. Leavitt, supra note 53, at 22. 
Finally, QIOs were criticized in the 2001 OIG Report because the QIO complaint process is not subject to public accountability. ${ }^{103}$ Aggregate data regarding QIO complaint investigations is not available on the CMS website. Such data can only be compiled through the often outdated and difficult to decipher information on individual QIO web pages:

A number of reports have identified obstacles to QIO effectiveness in the area of beneficiary complaints. In addition to the confidentiality constraint, the OIG and IOM have enumerated various "conflict of interest" issues that discourage QIOs from treating beneficiary complaints as a high priority activity. These include the fact that: 1) "CMS' contracts with [QIOs] treat complaints as a distinctly minor activity;", 104 2) "[QIOs] tend to be more oriented [toward] the medical community than to the beneficiary community;"105 3) QIOs do not consider beneficiaries primary clients; ${ }^{106} 4$ ) "technical assistance activities are incompatible with a strong regulatory function;" ${ }^{107} 5$ ) the QIO mission is to attract providers to enroll in quality improvement programs; ${ }^{108}$ and 6) evaluation of QIOs by CMS is based, in part, on hospital satisfaction ratings. ${ }^{109}$ In its 2006 report, the IOM recommended that CMS ease conflict of interest restrictions with regard to QIO subcontracts. The report suggested that, given limits on federal funding, "QIOs should be allowed to seek funds for quality improvement activities from providers and other organizations as appropriate."110 While this recommendation may help QIOs achieve their mandated objectives overall, loosening conflict of interest restrictions is bound to make it even more difficult for QIOs to juggle their various roles vis-à-vis health care providers and beneficiaries.

\section{ALTERNATIVE TO QIOS FOR RESPONDING TO BENEFICIARY COMPLAINTS}

In this section, we evaluate an alternative entity to QIOs for responding to Medicare beneficiary complaints. The alternative takes advantage of existing structures that currently respond to patient complaints about quality of care: state survey agencies and state medical boards. Below we describe how these entities respond to patient complaints and, in the final section, we discuss and

103. See 2001 OIG REPORT, supra note 2, at 13-14.

104. Id. at 14 .

105. Id. at 15 .

106. See 2006 IOM REPORT, supra note 3, at 112.

107. Id. at 113. "[W]orking collaboratively with providers and investigating their activities within a single contract can create an inherent conflict of interest for the QIOs." Id. at 114 .

108. Id. at 113.

109. Id. QIOs will be under more pressure to improve relations with providers in the eighth SOW because the weight of hospital satisfaction ratings will increase to twenty-five percent of QIO evaluation. Id.

110. Id. at 139. 
evaluate a combined alternative structure which builds upon the extensive experience these entities have in dealing with complaints about patient care.

In their reports, both the IOM and OIG stated that in addition to looking at existing organizations, CMS might consider establishing a new program or contract mechanism within CMS to respond to beneficiary complaints. ${ }^{111}$ As we approached the issue of where the beneficiary complaint process should be lodged, we considered the possibility of CMS or QIOs contracting with a new entity that would be devoted solely to handling and resolving Medicare beneficiary complaints. ${ }^{112}$ Presumably, this entity would be funded by money currently directed to QIOs for this process and would be subject to specific uniform criteria as to the handling of complaints. The benefit of creating a separate contract for this function would be the opportunity to establish an entity that would be specifically focused on responding to beneficiary complaints. At a minimum, this could reduce concerns about QIO conflicts of interest. ${ }^{113}$

We did not address the feasibility or benefits of such a new entity or how it might be constructed. Rather, on initial reflection, we concluded that such an entity would likely face some of the same problems that now trouble QIOs. These problems include lack of visibility, lack of available sanctions, and, possibly, the same confidentiality issues. In addition, if the contracts were given to newly created entities it would duplicate the efforts of existing organizations that currently receive and investigate complaints in each state and have considerable experience doing so.

Although there is merit to both solutions, we chose to assess the feasibility of relying on existing mechanisms with better coordination as, arguably, an important next step before moving forward to establishing a new entity. While existing mechanisms for complaint review have pros and cons, an understanding of how they function provides a possible alternative solution to a new entity or, in the case a new entity is created, can inform the characteristics of the new entity.

111. See 2006 IOM REPORT, supra note 3, at 112; 2001 OIG REPORT, supra note 2, at iii.

112. This is the model proposed in S. 1947, see supra note 10.

113. Having QIOs subcontract for specific tasks has been considered by CMS. During the drafting of the eighth SOW, CMS discussed the possibility of allowing or requiring QIOs to subcontract out those tasks for which the QIOs were unable to demonstrate competency (competency demonstrated through successful evaluation of performance under a previous SOW or other CMS-approved means). This idea was not well received by the QIO community, which argued that such a rule would be inconsistent with existing law and would favor non-QIOs because they would be "free to seek the work of QIOs without meeting the tests Congress established for QIOs" to qualify for funding. See Letter from David G. Shulke, Executive Vice President of the American Health Quality Association, to Secretary Mack McClellan, Administrator, CMS 5 (Sept. 20, 2004), http://www.ahqa.org/pub/uploads/AHQACommentsSOW8 DraftSummary.pdf (regarding the proposed eighth SOW). 


\section{A. State Survey Agencies}

State survey agencies have been mentioned by the IOM and OIG as potential alternatives to QIOs in responding to consumer complaints about quality of care in health care facilities. ${ }^{114}$ All fifty states and the District of Columbia have an office that is responsible for surveying and licensing health care institutions within that state. These agencies, which often have toll-free numbers and websites with information about how to make a complaint, routinely receive complaints and conduct complaint investigations.

The survey function is carried out under agreements between the state and the Secretary of DHHS in order to ensure that all providers participating in the Medicare and Medicaid programs meet minimum health and safety standards or "Conditions of Participation." These providers may include: ambulatory surgery centers, community mental health centers, end stage renal disease facility providers, home health providers, hospices, hospitals, intermediate care facilities for the mentally retarded, clinical laboratories, nursing homes, psychiatric residential facility providers, rehabilitation providers, and rural health clinics. These facilities are also licensed by states, which may have additional quality standards that the facilities must meet for licensing purposes. The survey and complaint response functions are supported, in part, by CMS, which provides funding to the states to carry out these tasks. ${ }^{115}$

The Association of Health Facility Survey Agencies (AHFSA), a national association of state survey agencies, provides a forum for directors of these offices to share information and address common interests. AHFSA has one paid staff person and a board of directors comprised of directors of state survey agencies. The mission of the organization is to "strengthen the role of its member state agencies in advocating, establishing, overseeing, and coordinating health care quality standards that will assure the highest practicable quality of health care for all state and federally regulated health care providers."116

\section{History of Responsiveness of State Survey Agencies to Consumer Com- plaints}

There is little information or data available about the responsiveness of state survey and licensing agencies to consumer complaints. To the extent data exists, it has focused primarily on complaints regarding nursing home care. In

114. See supra notes 2-3.

115. While every state is required by federal law to conduct surveys of nursing homes for purposes of Medicare certification, states vary in terms of the extent to which they conduct surveys of other institutional health care providers. Most states, for example, "have to a greater or lesser degree incorporated JCAHO accreditation into their hospital licensure standards." FURROW ET AL., supra note 14, at 8 . As a result, states may not routinely survey hospitals and rely on JCAHO to carry out this function.

116. Ass'n of Health Facility Survey Agencies, AHFSA Mission, http://www.ahfsa.org/ about\%20ahfsa.htm (last visited Jul. 16, 2007). 
1995, the Health Care Financing Administration (HCFA) (now CMS), was concerned about problems with state survey agency responses to nursing home complaints and "developed complaint investigation protocols for States" to follow. ${ }^{117}$ However, the General Accounting Office (GAO) determined in a 1999 report that such protocols were not sufficient. ${ }^{118}$ In that report, the GAO documented that states did not always investigate complaints of harm to nursing home residents promptly or at all, ${ }^{119}$ despite the fact that all state agencies must conduct certification surveys of nursing homes and "maintain procedures and adequate staff to investigate and report on the nursing home complaints they receive." $" 120$

In response to the GAO report, then-HCFA Administrator, Nancy-Ann DeParle, met with the Board of Directors of AHFSA to discuss the problems with complaint investigations and stress the urgency of improving all enforcement efforts. In addition, HCFA also:

- directed all [s]tate survey agencies to investigate any complaint alleging harm to a resident within 10 working days;

- reiterated to [s]tates that complaints alleging immediate jeopardy to residents must be investigated within two days;

- stressed to [s]tates that they must enter complaint information into [the HCFA] data system [OSCAR] promptly;

- published a regulation ... allowing [s]tates to impose fines for each instance of a violation; and

- [began having HCFA] [r]egional [o]ffice staff conduct surveys to verify nursing home resident complaints when necessary. ${ }^{121}$

Moreover, HCFA initiated a Complaint Improvement Project "to identify key elements of the complaint process, address resident and consumer concerns

117. Nursing Home Complaint Investigation: Hearing Before the S. Select Comm. on Aging, 106th Cong. (1999), available at www.cms.hhs.gov/apps/media/press/release.asp?Counter $=571$ (statement of Mike Hash, Deputy Adm'r Health Care Financing Admin.) [hereinafter Hash, Hearing Testimony].

118. See U.S. Gen. Accounting Office, Pub. No. GAO/HEHS-99-80, ComplaInt INVESTIGATION PROCESSES OFTEN INADEQUATE TO PROTECT RESIDENTS 16-17 (1999), http://www.gao.gov/new.items/he99080.pdf.

119. Id.

120. DHHS, OfFICE OF INSPECTOR GeNERAL, PUB. No. OEI-01-04-00340, NuRSING HoME COMPLAINT INVESTIGATIONS 1 (2006), http://oig.hhs.gov/oei/reports/oei-01-04-00340.pdf [hereinafter 2006 OIG NURSING HOME COMPLAINT REPORT] (citing Social Security Act, 42 U.S.C. $\$ \S$ $1395 \mathrm{i}-3(\mathrm{~g})(4)(\mathrm{A})-(\mathrm{g})(5)(\mathrm{a})(2003))$.

121. Hash, Hearing Testimony, supra note 117. 
about the process, and develop standards for prioritizing complaints and determining appropriate time frames for investigations." "122 In testimony at a hearing before the Senate Special Committee on Aging, then Deputy Administrator of HCFA, Mike Hash, stated that HCFA had determined that the key elements of the complaint process included:

- informing consumers of their right to make complaints and how to do so;

- the complaint intake process, including how complaints are received, classified and scheduled for investigation;

- the investigation process, including the training, knowledge, attitudes, and case load of investigators;

- the resolution process, for determining whether a complaint is substantiated;

- the administrative hearing process, including back-log of cases;

- the compliance or response process for addressing substantiated complaints, including the range and actual use of remedies and back$\log$ of actions; and,

- interactions between complaint investigations and licensure and certification systems, the legal system, and facility-level grievance or continuous quality improvement processes. ${ }^{123}$

Based on information received from the Complaint Improvement Project, Hash stated that HCFA would "develop [f]ederal minimum standards and produce a manual for States describing each element of a model complaint investigation process, how [s]tates should implement the process, and necessary training and staffing levels."124 Furthermore, Hash stated that HCFA would "specifically evaluate how well [s]tates respond to consumer complaints and how promptly and thoroughly they report investigation results to [HCFA] to determine whether they meet their survey responsibilities."125

In October 2000, CMS established the State Performance Standard Reviews which set performance standards for state survey agencies. These annual reviews "serve as CMS's primary oversight mechanism" for state agency performance in responding to complaints. ${ }^{126}$ The 2002 performance standards, for

122. Id.

123. Id.

124. Id.

125. Id.

126. See 2006 OIG NURSING HOME COMPLAINT REPORT, supra note 120, at 3. 
example, required that "[s]tate agenc[ies] triage[] and initiate[] investigation of 100 percent of the complaints [they] receive[] alleging or involving actual harm (high) to individuals consistent with CMS and [s] tate policy."127

A GAO Report released in 2005 indicated that CMS oversight of state survey activities had improved. ${ }^{128}$ However, the report recommended that CMS "[f]inalize the development of guidance to states for their complaint investigation processes and ensure that [the guidance] address[] key weaknesses, including the prioritization of complaints for investigation . . .."129

\section{Characteristics of the Current Complaint Process}

Over the last few years, CMS did two things to improve its oversight of state agency response to complaints. In 2004, CMS implemented the Aspen Complaints Incident Tracking System (ACTS) to standardize reported complaints, allowing analysis across state survey agencies and the ability to evaluate state complaint investigations. ${ }^{130}$ In March 2006, ${ }^{131} \mathrm{CMS}$ formalized its state guidance for complaint investigation processes, incorporating its recommendations (Management of Complaints and Incidents) into the State Operations Manual ("SOM"). ${ }^{132}$ The procedures are to be followed when complaints and reported incidents involve Medicare or Medicaid certified providers or suppliers.

The SOM acknowledges that complaints ${ }^{133}$ or related information can come from beneficiaries, their families, health care providers, citizens, public

127. Id. at 15 .

128. See U.S. Gov'T ACCOUNTABILITY OfFICE, PUb. No. GAO-06-117, NuRSING Homes: DESPITE INCREASED OVERSIGHT, CHALLENGES REMAIN IN ENSURING HIGH QUALITY CARE AND RESIDENT SAFETY (2005), http://www.gao.gov/new.items/d06117.pdf [hereinafter 2005 GAO REPORT]. In November 2002, CMS also initiated the Nursing Home Quality Improvement Initiative in an effort to, among other things, increase oversight over quality initiatives of state survey agencies and QIOs and to foster and improve communication between these agencies, as well as independent health quality organizations, advocates and nursing home providers. Hash, Hearing Testimony, supra note 117.

129. 2005 GAO REPORT, supra note 128, at 52.

130. See 2006 OIG NURSING HOME COMPLAINT REPORT, supra note 120 , at $\mathrm{i}$. The ACTS "includes more comprehensive complaint information than the previous repository for nationwide complaint data, the Online Survey Certification and Reporting system ("OSCAR")."Id.

131. CMS, Transmittal 18 (2006), http://www.cms.hhs.gov/transmittals/downloads/ R18SOMA.pdf.

132. CMS, STATE Operations MANUal (2006), Chapter 5, http://www.cms.hhs.gov /manuals/downloads/som107c05.pdf [hereinafter SOM]. "As part of the agreements with CMS under which State survey agencies operate, SOM requirements are contractually binding on Medicare-certified and Medicare-Medicaid dually certified nursing homes." 2006 OIG NURSING HOME COMPLAINT REPORT, supra note 120, at 1.

133. The SOM defines a complaint as an "allegation of noncompliance with Federal and/or State requirements" (SOM, supra note $132, \S 5010$ ), and states that "complaints that are not directly related to federal requirements" may be forwarded to the "appropriate agency(ies) for follow-up and investigation." Such complaints may include allegations of "Medicare/Medicaid fraud, complaints against individual licensed practitioners, and billing issues." Id. $§ 5000.1$. Complaints alleging non condition-level noncompliance may be referred to the relevant accred- 
agencies, or media reports and that after a complaint is received subsequent communication with the complainant may be necessary in order to evaluate and prioritize the complaint. The SOM provides a list of intake information that state survey agencies should collect in the initial or follow up contact with the complainant. This information includes:

- the complainant's name, address, telephone, etc.;

- the individuals involved and affected;

- the narrative and specifics of the complainant's concerns including the date, and time of the allegation;

- the complainant's views about the frequency and pervasiveness of the allegation;

- the name of the provider/supplier including location (e.g., unit, room, floor) of the allegation, if applicable;

- how/why the complainant believes the alleged event occurred;

- whether the complainant initiated other courses of action, such as reporting to other agencies, discussing issues with the provider, and obtaining a response/resolution; and

- the complainant's expectation/desire for resolution/remedy, if appropriate. ${ }^{134}$

As part of the intake process, the survey agency ("SA") is to provide the complainant with the following:

- the policies and procedures for handling intakes including the scope of the SA's regulatory authority and any considerations pertaining to confidentiality;

- the course of action that the SA or RO135 will take and the anticipated time frames;

- information about other appropriate agencies that could provide assistance including the

iting organization. Id. $\S 5010.2$.

134. Id. $\$ 5010.1$.

135. RO refers to the CMS Regional Office. The SOM provides that the SA must forward certain allegations to the CMS Regional Office. CMS ROs are "responsible for monitoring the SAs' management of complaints and incidents to assure that the SAs are complying with the provisions set forth in [f]ederal regulations, the SOM, and CMS policy memoranda." Id. § 5050. 
name and telephone number of a contact person, if available; and

- an SA contact name and number for follow-up by the complainant. ${ }^{136}$

SAs are expected to input all complaint data from initial intake and investigation through final disposition into ACTS. "[D]ata entered into ACTS is subject to [f]ederal laws governing disclosure and the protection of an individual's right to privacy."137

The SOM includes maximum time frames for SAs to initiate investigations in response to complaints of immediate jeopardy and complaints regarding a high or medium probability of harm at nursing homes, non-deemed providers other than nursing homes, and deemed providers. ${ }^{138}$

The SOM further provides guidance to SAs in responding to complainants. Such responses generally should include:

- acknowledgement of the complainant's concerns;

- a statement of the SA's regulatory authority to investigate the complaint and any statutory or regulatory limits that may bear on its authority to conduct an investigation;

- a summary of the SA's investigation methods (e.g, on-site visit, written correspondence, telephone inquiries, etc.);

- date(s) of investigation;

- an explanation of the SA's decision-making process including definitions of terms used;

- a summary of the SA's finding, ${ }^{139}$

- a description of follow-up action, if any, to be taken by the SA (e.g., follow-up visit, plan of correction review, no further action, etc.); and

- appropriate referral information (i.e., other agencies that may be involved). ${ }^{140}$

136. Id. $\S 5010.2$. The QIO Manual requires that similar information be provided in the initial follow-up letters to complainants. See CMS, QIO MANUAL, supra note 37, §5010.

137. SOM, supra note $132, \S 5060$.

138. Id. $\S 5070$. An organization is considered "deemed" when a national accrediting commission, such as the Joint Commission, provides CMS with verification that the organization meets or exceeds appropriate federal requirements. A "deemed" organization therefore is deemed to meet Medicare (or Medicaid) certification requirements.

139. "The summary should not compromise the anonymity of individuals, or include specific situations that may be used to identify individuals, when anonymity has been requested or is appropriate in the judgment of the SA." Id. $\S 5080.1$. 
Although this guidance is relatively new, a July 2006 OIG report provides some information about the compliance of state SAs with the State Performance Standards and the SOM provisions in responding to complaints about nursing homes. Significant findings from the OIG included the following:

- "State agencies did not investigate some of the most serious nursing home complaints within SOM-required timeframes." In 2004, based on the State Performance Standard Reviews, SAs did not investigate seven percent of complaints alleging "immediate jeopardy" in the required forty-eight hours. ${ }^{141}$ In addition, SAs did not investigate twenty-seven percent of complaints alleging actual harm within the required ten day timeframe. ${ }^{142}$

- State agencies have not taken full advantage of the ACTS. SAs' "use of their own data systems in addition to the ACTS, technical problems with the ACTS, and lack of training have hindered its use as a complaint management tool."143

- 'Most state agencies' written policies and procedures generally incorporate the SOM; how-

140. Id. The SOM recognizes that many states have separate procedures specifying how SAs should respond to and manage complaints. According to CMS, "[w]henever possible, [s]tate and [f]ederal requirements should be integrated to avoid unnecessary duplication." Id. § 5050 .

141. 2006 OIG NURSING HOME COMPLAINT REPORT, supra note 120 , at 8 .

142. Id. at 9. State Performance Standards for 2004 included the following:

- "For ninety percent of randomly selected complaints, the CMS regional office must agree with the state agency's prioritization of the complaint;"

- "The [s]tate agency must investigate all immediate jeopardy complaints onsite within two working days;"

- "The [s]tate agency must investigate all complaints alleging actual harm (high) onsite in an average of ten working days, with all investigations completed within twenty working days;"

- "The [s]tate agency must follow CMS instructions for handling complaints for no less than eighty percent of nursing home complaints. These instructions include contacting complainants with investigation results and having qualified surveyors complete the nursing home survey, among others."

Id. at 3-4.

143. Id. at ii. 
ever, those policies do not incorporate all of the SOM's guidelines."

- "[M]any follow-up letters to complainants lacked meaningful information."145 Although SAs appeared to do a good job sending out some kind of response to complainants, the responses "often lacked comprehensive information about the complaints such as acknowledging the complainant's concern and summarizing the investigation methods."

- "CMS oversight of nursing home complaint investigations is limited." 146

With respect to each of these measures, state performance varies significantly from state to state. ${ }^{147}$ A significant majority of states, for example, scored well on timeliness in responding to complaints of immediate jeopardy, responding to at least ninety percent of such complaints within the two-day window. Yet, ten states failed to respond in the required timeframe between ten and thirty-three percent of the time, and one state failed to respond in a timely manner in over ninety percent of cases alleging immediate jeopardy. ${ }^{148}$ The inability of states to respond within the required time frames may be attributed to insufficient agency staffing - both in terms of number of staff and staff competence to evaluate complaints. Moreover, a consistent concern across state agencies is a lack of adequate resources to respond to complaints in a timely manner.

Regarding SA responses to complaints, the OIG found that "[w]hile most of the [s]tate agencies' policies direct their staff to send follow-up letters to complainants, many of the policies provide little or no detail about the required content of [the] letters." 149 Of the forty-two policies reviewed by the OIG, "only [nine] require[d] that follow-up letters to complainants include all of the components cited in the SOM.",150

The OIG reviewed 498 nursing home complaints that resulted in an onsite investigation. The review indicated that state agencies "generally collected appropriate information during intake, employed qualified professionals to assign priorities to the complaints, and provided the complainant ... with a written report of the investigation findings."

144. Id.

145. Id.

146. Id.

147. See id. at 28 tbl.4.

148. See id.

149. Id. at 13 .

150. Id.

151. Id. 
corporating each of the elements listed by the SOM for inclusion in the response to complainants. ${ }^{152}$

In a letter to the OIG regarding its findings, then-CMS Administrator Mark McClellan pointed out that the number of completed nursing home complaint investigations undertaken by state agencies rose by thirty-seven percent from 1999 to 2005 (from 32,422 to 44,677 ). The increase, according to McClellan, "represents both stronger performance and stronger commitment to be as responsive as possible to nursing home residents and their families."

While state agencies vary considerably with regard to their responsiveness to complaints, there are indications that many states are doing a competent job and have systems in place to effectively track complaints and responses. Although many states continue to struggle with inadequate staffing, a number of states have significantly improved their complaint responses over the last two to three years due to federal requirements.

Although there is no uniform national data available on how often state survey agencies implement various types of corrective actions or sanctions under state laws, these agencies have a range of interventions available to them with which to respond to findings that a facility is providing poor quality care. In addition to issuing letters of deficiency and requiring corrective action, agencies may levy civil monetary penalties or revoke a facility's license. While SAs rarely do the latter, they routinely require corrective action plans and follow up with providers to ensure that action is taken. SAs also provide due process protections to providers when levying fines or revoking a license; such protections include an appeal process for providers who contest these actions. In addition, federal rules require that SAs provide an informal dispute resolution process for nursing homes contesting citations for deficiencies. ${ }^{154}$

While SAs generally excel in tracking and responding to beneficiary complaints, a major shortcoming of relying solely on SAs to perform the beneficiary review function is that their scope of authority is limited to institutional providers. In determining whether relying on SAs to respond to Medicare beneficiary complaints is appropriate, it would be helpful to know the percentage of complaints received by QIOs that address institutional care. One might also argue that health care institutions have significant control over physician practices and

152. See id. at 14 tbl.3 (summarizing the OIG's findings on this performance measure). According to the table, letters were missing acknowledgement of the complainant's concerns forty-seven percent of the time, a summary of the investigation methods fifty percent of the time, a discussion of the SA's decision making process twenty-seven percent of the time, and the summary of the SA's findings nine percent of the time. Id.

153. See id. at 29 app. C (Letter from Mark B. McClellan, Administrator, CMS, to Daniel R. Levinson, Inspector General, DHHS (May 17, 2006) (responding to OIG Draft Report Nursing Home Complaint Investigations (OEI-01-04-00340)).

154. 42 CFR $\S 488.331$ and Chapter 7, Survey and Enforcement Process. For non-federal surveys, the state must offer a facility an informal opportunity, at the facility's request, to dispute survey findings upon the facility's receipt of the official statement of deficiencies. For federal surveys, CMS offers a facility an informal opportunity, at the facility's request, to dispute survey findings upon the facility's receipt of the official statement of deficiencies. Id. 
other health care providers, and therefore, SAs, by effectuating changes in institutional practices, might be an effective vehicle for influencing practitioner behavior.

\section{B. State Medical Boards}

The OIG also mentioned state medical boards as possible entities to take on the review of Medicare beneficiary complaints about quality of care. ${ }^{155}$ In this section we describe the scope and activity of these boards and their response to consumer complaints involving physician practices.

Legislatures in every state have enacted a Medical Practice Act that defines the proper practice of medicine and the medical board's scope of responsibility to regulate that practice within the state. ${ }^{156}$ Most states have separate boards for each medical specialty. State medical boards license providers, investigate complaints, discipline those who violate the law, conduct provider evaluations and facilitate rehabilitation of providers when appropriate. The basis for discipline does not vary significantly across the states, with most states including "incompetence; gross negligence; aiding and abetting the unlicensed practice of medicine; conviction of a felony or other crime . . .; unlawful sale of drugs; impairment due to drugs or alcohol; and professional discipline in another state . .."157 State medical boards judge the potential offenses that come before them under one of two different standards. Nationally, about two-thirds of state medical boards use a "preponderance standard" and one-third use the higher "clear and convincing evidence" standard. ${ }^{158}$

State medical boards routinely receive complaints about provider behavior and practice and are a potential vehicle to receive Medicare beneficiary complaints regarding substandard care. Because physicians (unlike other health care providers) generally work independently and are not directly disciplined by the facilities in which they practice, our focus will be on physician boards. ${ }^{159}$

155. 2001 OIG REPORT, supra note 2, at iii.

156. The Tenth Amendment of the United States Constitution authorizes this legislation, which allows States to establish laws and regulations protecting the health, safety, and general welfare of their citizens. See U.S. CoNST. amend. X.

157. FURROW ET AL., supra note 14, at 82 .

158. See 2006 DHHS BOARD STUDY, supra note 69, at 14-15. Under a "preponderance of the evidence" standard, a board may make a disciplinary finding from a mere preponderance of the evidence, that is, that an offense more likely than not occurred. Id. Under a "clear and convincing evidence" standard, a board may make a disciplinary finding only if the board finds that there is little doubt that the offense took place.

159. Arguably, complaints involving the large majority of other health professionals could be addressed by working through health care institutions. Some would argue that institutions, at least hospitals, also have considerable control over physicians via the granting of practice privileges. Certain specialists are very dependent on hospital privileges, and while hospitals may be reluctant to take away privileges from physicians and thereby lose referral volume, recent commentaries have encouraged hospitals to adopt a more central role in controlling physician practices. See Lucian L. Leape \& John A. Fromson, Problem Doctors: Is There a System-Level Solution? 144 ANNALS INTERNAL MED. 107, 107 (2006). 
The structure and authority of state medical boards vary from state to state. Some boards are independent and maintain all licensing and disciplinary powers; whereas others are part of a larger umbrella agency, such as a state department of health. State medical boards are typically made up of volunteer physicians and members of the public who, in most cases, are appointed by the governor and paid a nominal stipend for their service. The criticism that boards are "captured" by the profession has received a great deal of attention in the past decade and now, almost every state requires that its board include some number of lay members, on the theory that they are more likely to hold errant physicians accountable. ${ }^{160}$

The majority of state medical boards typically employ an administrative staff including an executive officer, attorneys, investigators, and licensing personnel. The state legislature determines the financial resources of most boards. Some boards are funded directly from physician licensing and registration fees. Board spending per thousand physicians ranges widely and is primarily affected by licensure fee levels and state budgetary policies. A 2006 DHHS study of state medical boards reported the need for increased budgets to improve their complaint processes. ${ }^{161}$ This report further noted that "[n]ationally the best funded $25 \%$ of Boards receive more than double the resources per instate practicing physician as their lower funded counterparts in the bottom $25 \%$."162

While state medical boards play a vital role in the realm of medical complaints, there are significant differences between the fifty-one boards that exist across the country. ${ }^{163}$ Most importantly, not all state medical boards investigate complaints. ${ }^{164}$ In seven states, this duty is delegated to another agency, most commonly the state's health department. ${ }^{165}$ Another important difference between boards is their degree of independence from state agencies. ${ }^{166}$ While most state medical boards are independent, a good number are semi-

160. See 2006 DHHS BoARD STUDY, supra note 69 , at 11.

161. See id. at ix.

162. Id. at 16.

163. A large part of the information relating to the nation's medical boards in this paper comes from the Federation of State Medical Boards' 2003 Exchange, a compendium of information about state medical boards published every two to four years. See FEDERATION OF STATE MEDICAL BOARDS, EXCHANGE tbl.29 (2003) [hereinafter FSMB EXCHANGE]. The Exchange is based on surveys completed by the medical boards that comprise the Federation of State Medical Boards ("FSMB"). The FSMB is a national not-for-profit organization representing the seventy medical boards of the United States and its territories, including fourteen state boards of osteopathic medicine. For purposes of this paper, we include information relating to the medical boards in the fifty U.S. states and the District of Columbia. It should be noted that three Boards (Vermont, New Jersey, and South Dakota) did not respond to the FSMB survey. In addition, New York has two boards - an advisory board and a professional conduct board. We consider them together for purposes of this report.

164. Id. at tbl.29.

165. See id. at tbls. 5 \& 8. These states include Arkansas, Connecticut, Florida, Hawaii, Michigan, Nebraska, New York, and Utah.

166. See id. at tbl.8. 
independent (generally part of the state's health department) and some are purely advisory.

Like the QIOs, all fifty-one state medical boards have a website available to the public, which vary in terms of their usefulness to patients. ${ }^{167}$ Public Citi$z^{168}$ has analyzed the "user-friendliness" of the fifty-one board websites, ${ }^{169}$ specifically with regard to online physician profiles, and found huge differences between states. ${ }^{170}$ Beyond a website, boards also vary greatly in terms of accessibility. More than half publish a public newsletter, while less than half have a toll-free number available to the general public. ${ }^{171}$ State medical boards also vary as to whether they assure confidentiality to those who report violations. ${ }^{172}$

On two basic measures, most state medical boards are responsive to complainants: forty-eight of the fifty-one boards acknowledge complaints made to them ${ }^{173}$ and forty-nine boards inform complainants of the outcome of the complaint. ${ }^{174}$ Unlike the QIOs, which are currently forbidden by CMS from revealing individual practitioner information without the practitioner's permission, most state medical boards inform complainants of the outcome of an investigation. ${ }^{175}$

Virtually all boards have experience conducting investigations, specifically in response to health care quality complaints. Although state medical boards are generally staffed by practitioners, the 2006 DHHS Report found that many boards have difficulty obtaining sufficient medical and legal expertise at both the complaint screening stages and in preparing for and conducting formal testimony at hearings. ${ }^{176}$

Speed of complaint resolution varies greatly by state. In the typical state, about ten percent of cases take more than 360 days to resolve. ${ }^{177}$ According to the 2006 DHHS Board Study, "[c]losure times vary considerably according to

167. See id. at tbl.16.

168. Public Citizen is a Washington D.C.-based consumer advocacy organization founded in 1971 by Ralph Nadar.

169. Meredith Larson et al., Public Citizen's HeAlth ResearCh Group, Pub. No. 1791, REPORT OF DOCTOR DISCIPLINARY INFORMATION ON STATE WEB SITES: A SURVEY AND RANKING of State Medical and Osteopathic BoARD Web Sites, at A-12 tbl.7 (2006), http://www.citizen.org/documents/1791MedBoard2006FullReportWeb.pdf.

170. Id. at 18. Physician profiles are legislatively mandated in most of the states that did well in the survey and not mandated in states that did poorly in the survey. Id. at 19 . In this study, Public Citizen evaluated the websites based on the following criteria: availability and types of physician-identifying information; state board disciplinary action information; hospital disciplinary action information; federal government disciplinary action information; malpractice and conviction information; and user-friendliness. Id. at 5-6. According to the evaluation, New Jersey hosts the most user-friendly website and North Dakota hosts the least user-friendly. Id.

171. See FSMB EXCHANGE, supra note 163, at tbl.16.

172. Id. at tbl.18.

173. Id. at tbl.35. Florida, Indiana, and Utah are the exceptions.

174. Id. Indiana and Utah are the exceptions.

175. Id.

176. See 2006 DHHS BoARD STUDY, supra note 69 , at vii.

177. Id. 
how far through the disciplinary process a case proceeds. Nationally, in 2003, cases resolved before or during investigation averaged 180 days from intake to closure, 425 days for cases closed after investigation but before hearing, and 675 days to reach hearing." 178 Furthermore, all of the states in the study reported a backlog in cases. ${ }^{179}$

Unlike QIOs, all state medical boards have broad disciplinary decisionmaking ability that they routinely employ. ${ }^{180}$ The following table lists the most common board sanctions and the percentage of states in which they are available.

\begin{tabular}{|c|c|c|}
\hline \multicolumn{3}{|c|}{$\begin{array}{c}\text { Wailabilit! of Sanctions } \\
\text { (percentage of states w ith sanctions) }\end{array}$} \\
\hline Type of Sanction & III States & Gase Study states \\
\hline Revocation of license & $100 \%$ & $100 \%$ \\
\hline Suspension of license & $100 \%$ & $100 \%$ \\
\hline $\begin{array}{l}\text { License limitation or re- } \\
\text { striction }\end{array}$ & $100 \%$ & $100 \%$ \\
\hline $\begin{array}{l}\text { Stipulations or consent } \\
\text { agreements }\end{array}$ & $100 \%$ & $100 \%$ \\
\hline Probation & $98 \%$ & $100 \%$ \\
\hline $\begin{array}{l}\text { Summary suspension of } \\
\text { license }\end{array}$ & $96 \%$ & $100 \%$ \\
\hline Public reprimand & $94 \%$ & $100 \%$ \\
\hline Collection of fine & $87 \%$ & $100 \%$ \\
\hline Letter of Concern & $64 \%$ & $33 \%$ \\
\hline $\begin{array}{l}\text { Collection of costs of pro- } \\
\text { ceedings }\end{array}$ & $55 \%$ & $50 \%$ \\
\hline Letter/decree of censure & $49 \%$ & $67 \%$ \\
\hline Private reprimand & $43 \%$ & $17 \%$ \\
\hline SOURCE: 2006 DHHS B & Study ${ }^{181}$ & \\
\hline
\end{tabular}

178. Id. at 32 .

179. Id. at 35 .

180. See FSMB EXCHANGE, supra note 163, at tbl.39.

181. 2006 DHHS BOARD STUDY, supra note 69, at 29 exh.16. 
Some boards also utilize more creative remedies, such as mentoring or supervision of provider practices, mandatory education programs, limitations on practice, e.g., prescribing. All state medical boards that conduct investigations and engage in disciplinary actions have administrative due process procedures to protect providers. Many boards rely on State Attorney Generals' offices for legal representation in disciplinary cases. ${ }^{182}$

As set forth in the medical practice acts in most states, quality of care is the guiding principle behind the state medical boards' role in licensure and discipline. However, many boards in the 2006 DHHS Report commented that the complaint process is reactive, and they would prefer to engage in more proactive quality improvement activities. ${ }^{183}$ In that report, state medical boards admitted they are driven by consumer complaints and these complaints result in a large number of costly investigations that lead to few actionable cases. ${ }^{184}$

The amount of information released to the public regarding investigations and sanctions varies widely among the states. Thirty-three out of fifty-one state medical boards issue an annual report that is available to the public and media. ${ }^{185}$ Additionally, the information in these reports varies greatly. ${ }^{186}$ The information states release to the public about physicians licensed in that state also differs, although most (forty-nine) reveal physicians' disciplinary history. ${ }^{187}$ State medical boards, however, have come under greater pressure in recent years to release more information to the public. As a result, many states have passed laws requiring increased disclosure, especially regarding physician profiles. ${ }^{188}$

The most salient characteristic of state medical boards (and most problematic for giving boards responsibility to respond to Medicare beneficiary complaints) is that they are wholly creatures of state law. The federal government has no power to influence state medical boards to coordinate activities, make reports, or harmonize their activities to fit into a national framework, regardless of whether a board functions independently within a state or as part of the state's health department. For example, the federal law creating the National Practitioner Data Bank ${ }^{189}$ "requires" boards to report certain adverse actions taken against physicians to a national data bank. ${ }^{190}$ Although the word "re-

182. See FSMB EXCHANGE, supra note 163 , at tbl.39.

183. See 2006 DHHS BOARD STUDY, supra note 69 , at 44-45.

184. Id. The DHHS Board Study found that many board members and managers wanted to do more for safety than simply reacting to complaints. Some suggested other proactive alternatives to complaint-based discipline, including audits of physician practices, non-disciplinary use of clinical assessment centers, and efforts to encourage ongoing maintenance of competencies. Id. at 65 .

185. See FSMB EXCHANGE, supra note 163, at tbl.6.

186. Id.

187. Id. at tbls. 40 \& 43 . Louisiana and Wyoming are the exceptions.

188. See LARSON ET AL., supra note 169 , at 3 .

189. See Health Care Quality Improvement Act of 1986, Title IV of Pub. L. 99-660, 100

Stat. 3784 (codified as amended at 42 U.S.C. $\$ \S 11101-11152$ ).

190. See 42 U.S.C. $\S 11133$ (2000). 
quire" is used throughout the statute and regulations, if a board refuses to transmit the information specified under the law, CMS can only designate another qualified entity to report such information. ${ }^{191}$

\section{Combined Entity Including State Survey Agency and State Medical Board}

Given that state survey agencies are limited to dealing only with facilitybased complaints and that medical boards are authorized to deal only with individual provider-based complaints, an alternative entity that combines the expertise of State Survey agencies and State Medical Boards in responding to beneficiary complaints but also relies on QIOs for analyzing the complaints received by these two entities may provide the most effective way to respond to beneficiary complaints.

A major problem with the current system is duplication of effort and failure of coordination among various entities responding to complaints about poor quality health care. Complaints are potentially received by a number of agencies, including the SAs, the state medical and other health professional boards, QIOs, the Joint Commission on Accreditation of Health Care Organizations (the "Joint Commission), the Nursing Home Ombudsman, and Medicare contractors. There appears to be little, if any, coordination or sharing of information regarding complaints among these agencies.

We were surprised to learn that many directors of SAs did not know that QIOs received beneficiary complaints. As compared to SAs and state medical boards, the QIOs receive significantly fewer complaints. One of the state directors with whom we spoke said he was unaware that the QIO in his state received beneficiary complaints. After he learned, from our inquiry, that this occurred, he called his state QIO and asked about the beneficiary complaint process and how many complaints the QIO had received in the previous year. The QIO staff person said the QIO had received 100 complaints. The SA Director thought this was somewhat comical as his state office receives approximately 100 complaints in half a day. Clearly, it is the case that the QIOs do not necessarily share their complaints with the state survey agencies. This is despite the fact that some sharing of information is envisioned by the QIO Manual. ${ }^{192}$ Without a complete picture of the types of complaints that are being

191. See 45 C.F.R. $\S 60.8$ (a) (2006).

192. According to the QIO Manual:

The State health agency or other appropriate State or local agency used by CMS to perform survey/certification and review functions for Medicare (the "SA") is not required to refer all complaints to [the QIO] that involve quality issues. In some States, it is the law that the SA reviews all complaints it receives. To assist [the QIO] and the SA in understanding [the QIO's] areas of responsibility, [the QIO should] develop a written plan with the SA that explains the types of complaints each will be responsible 
made by consumers about health care institutions and providers, it is difficult for QIOs or any quality improvement organization to make or recommend modifications to a system to improve quality and patient safety. An alternative system that would require coordination among existing agencies and increase the complaint data going to QIOs is described below.

\section{Elements of an Alternative Complaint Entity}

1. SAs and state medical boards would be designated as the official place for a Medicare beneficiary to lodge a complaint about quality of care received. (Complaints about non-physician health care providers, e.g., nurses, therapists, etc., who typically provide care in an institutional setting, would be handled by the SA.) This may or may not increase the number of complaints these agencies receive. It may also require the state agencies to have a broader scope of complaints over which they have authority to respond, e.g., complaints that are not violations of state licensing standards but meet the review requirement standards for Medicare beneficiary complaints.

2. SAs and state medical boards would investigate all formal complaints, determine if there is a deficiency in the care provided or an issue regarding quality of care, determine what type of corrective action is necessary, and work with the institution and/or provider to implement such corrective actions or impose civil monetary penalties or other form of sanctions as appropriate.

3. These agencies would provide individualized responses to complainants via letter, which would include the agencies' findings and any action taken.

4. In order to attain some standardization in response practices and consistency across jurisdictions, CMS would put in place guidelines for responding to such complaints, similar to those already in place for SAs in the CMS state operations manual. CMS would also monitor performance, as it currently does over certain aspects of SA performance.

5. State agencies would receive additional funding for these new tasks.

6. Each state would designate an individual within the relevant department (health, consumer, etc.) to oversee this process and attempt to coordinate efforts of the SA and the professional licensing boards when a complaint involving multiple providers is received.

for reviewing, and the exchange of information involving deficiencies in survey and certification requirements or confirmed quality concerns. [The QIO should] involve [the QIO's] Regional Office Project Officer when [the QIO] and the SA cannot agree on what types of issues each should review or when there are multiple issues that require Project Office coordination/assistance."

CMS, QIO MANUAL, supra note 37, § 5015. 
7. The state agencies would forward all complaints and follow up action taken to the State QIO.

8. Ideally, other agencies such as the Joint Commission and Medicare contractors would also be required to submit complaints to the QIO.

9. The QIOs would respond to requests from SAs and the medical boards for technical assistance, use information about complaints to identify priorities for technical assistance, and work with institutions and providers to implement the necessary changes.

10. QIOs would share complaint information with the relevant CMS regional office. This would ensure that the appropriate regional offices have the relevant information and can feed that information back to the relevant local QIOs. The regional offices would also have the authority to consider referral to the OIG for sanctions in cases where the state agencies decide not to sanction or to administer additional sanctions beyond those meted out by the state agencies.

11. QIOs would post uniform data about complaints received by the state entities on their websites so that it would be available to the public. This could take the form of an annual quality report.

12. Regional offices would submit all information to a national database. The analysis of data at a national level, using expert panels, is likely to be more effective in identifying quality improvement priorities nationally and regionally. This database would have a structure and classification/nomenclature that would create standardization, allow data analysis for safety/QI and facilitate public reporting. It could also be designed to track timeliness and even include beneficiary satisfaction data. Identified priorities could also be shared with local QIOs for implementation.

This alternative is consistent with the recommendation of the IOM to shift the review of beneficiary complaints from the QIOs to other entities. ${ }^{193}$ The IOM report argued that this shift should be made for a number of reasons. For example, it would allow QIOs to focus on quality improvement and performance measurement which are "incompatible with a strong regulatory function."194 Moreover, the report points to the small number of complaints received by QIOs. ${ }^{195}$ Finally, the IOM argues that there are a number of other organizations already responding to consumer complaints and some of them have greater visibility among consumers than the QIOs. The report specifically states that "[a]mong the entities considered should be state health departments and the state Survey and Certification agencies, which already contract with

193. See 2006 IOM REPORT, supra note 3, at 113.

194. Id.

195. See id. 
CMS to conduct certain functions for the Medicare program, including the review of all quality-related complaints for nursing homes."196

\section{Assessment of Alternative Complaint Entity}

In evaluating this alternative to QIO for receiving and responding to Medicare beneficiary complaints we used two sets of criteria. The first are those which the OIG called in its 2001 report the "characteristics of an effective complaint process." 197 They include accessibility, investigative capacity, interventions and follow-through, quality improvement orientation, responsiveness, timeliness, objectivity, and public accountability. ${ }^{198}$ In addition to these characteristics identified by the OIG, we added scope of authority, adequate resources, coordination with other entities, due process (i.e., fairness to the provider), consistency across jurisdictions, and range of responses/remedies (apology, mediation, quality improvement, compensation, sanctions, etc.) to the list of "effectiveness criteria.",199

The combined entity, would fare well on many (though not all) of the criteria relevant for evaluation of a complaint system. Below, we assess the alternative entity on each of the listed criteria as compared to the QIOs.

Accessibility: SAs and state medical boards are much more accessible than QIOs and they already receive a much larger volume of complaints than QIOs. Consumers and beneficiaries are most likely to lodge a complaint with SAs and state medical boards. SAs are required to have hotlines to receive complaints concerning nursing homes and home health care. We found that states may also have hotlines for other facilities, such as hospitals.

Investigative Capacity: SAs employ individuals with health care expertise to survey health care facilities. Most often, these individuals are nurses trained by CMS and the states. Additional medical expertise may be obtained from the state medical board. A few state medical boards already contract with their QIOs for additional medical expertise. A closer nexus between state agencies and QIOs regarding complaint activity could facilitate this consultation process. Survey agencies have rapid access to clinical records and broad investigative authority.

Interventions and Follow Through: SAs and medical boards have many more tools at their disposal than QIOs to intervene to take corrective action in

196. Id. at 115 .

197. 2001 OIG Report, supra note 2, at 6.

198. Id. Appendix A, infra, includes a description of each of the criteria identified in the 2001 OIG Report.

199. Several of these criteria are described in more detail by a companion paper to this report by Peter A. Hollmann, M.D. Peter A. Hollmann, Elements and Considerations for Developing a Medicare Beneficiary Complaint Process to Address Quality of Care Concerns: The Medical Perspective, http://www.Medicareadvocacy.org/QIOConference/Background/Back groundPaper.MedicalPerspective.pdf. 
response to complaints. They routinely issue deficiency letters and request and monitor corrective action plans.

Quality Improvement Orientation: The alternative arrangement would allow QIOs to do what they do best: identify priorities for technical assistance and suggest changes to improve quality of care. The volume of complaints generated by SAs and state medical boards would provide ample data for local, regional and nationwide analysis to discern patterns of poor quality care. A regional and national focus would also allow for a national database and a national expert panel to analyze the available data.

Responsiveness: SAs and state boards already have systems in place for responding to complainants. CMS is improving its oversight of SA responsiveness to complaints, which will likely lead to greater responsiveness on the part of SAs. If this alternative arrangement were to be put in place, CMS could expand its oversight of response to beneficiary complaints and provide guidelines similar to those already in place for SAs to respond to these complaints.

Timeliness: Both QIOs and SAs have experienced problems in responding in a timely manner to complainants. SAs, however, are being scrutinized by CMS on this measure and pushed to improve timeliness of response. State medical boards are perhaps weakest on this measure, in part, because they have no federal timelines with which to comply.

Objectivity: The proposed arrangement would deal with concerns that have been levied at QIOs regarding their perceived conflicts of interest. The function of SAs and state medical boards is to protect patients from harm. Unlike QIOs, which are required to work closely with providers to change practice patterns, SAs have a singular function, and at least theoretically, do not have the same conflicts that confront QIOs. In addition, SAs, in responding to complaints, often are able to rely on objective criteria and standards set forth in regulations. This is perhaps most true when investigating nursing homes which are heavily regulated. QIOs, in contrast, must rely on somewhat subjective evaluation by reviewing physicians. By distancing QIOs from the complaint process they would be able to continue to work closely with health care providers to make improvements in the system. SAs and Boards, however, could continue to play a strong role in enforcement without jeopardizing the quality improvement process.

Public Accountability: The proposed arrangement could also be structured to allow for greater public accountability by making reports based on aggregate complaint data available to the public. Expanding complaint information to be included in a new national database, including all Medicare beneficiary complaints, would also improve oversight and public accountability.

Scope of Authority: SAs and state medical boards have a scope of authority that is at the same time both broader and narrower than QIOs. SAs, for example, have authority to respond to complaints from all patients and consumers regarding care received at health care facilities subject to state licensure requirements. On the other hand, SAs are not responsible for responding to 
complaints regarding individual health practitioners. In contrast, state boards are limited to dealing with complaints about individual practitioners and do not address complaints about facilities. QIOs are limited to responding to complaints by Medicare beneficiaries, but such complaints can be about individual practitioners or health care institutions. The combination of state survey agencies and state medical boards would have authority over virtually all Medicare beneficiary complaints.

Adequate Resources: While it is unlikely that the shift in responsibility would significantly increase the number of complaints that SAs or state medical boards currently receive, this alternative calls for additional funds to be given to these entities to improve their complaint response function. These funds could come from funds now awarded to QIOs.

Coordination with Other Entities: One of the principal advantages of the proposed alternative is the formalization of coordination with other entities within a state. Currently, SAs handle complaints about institutional providers and routinely refer complaints about individual practitioners to the appropriate state boards; Boards handle complaints about individual providers; and QIOs handle a small number of complaints about both. Our proposal would ensure that these groups coordinate their efforts to avoid duplication or contrary efforts.

Due Process: Both state medical boards and state survey agencies have due process mechanisms in place to protect practitioners and providers from arbitrary punishment. State medical boards uniformly offer formal notice and appeal procedures to practitioners charged with violation of licensing and disciplinary standards. State survey agencies generally have an appeals process in the case of fines or license revocation. The due process procedures of both state agencies would need to be harmonized to ensure procedures were uniform throughout.

Consistency Across Jurisdictions: This may be the most significant weakness of this alternative proposal. Survey agencies and medical boards vary significantly from state to state, possibly more so than QIOs, which operate under contracts that conform to a national "scope of work" developed by CMS. These variations are likely due to variations in resources and expertise. To some extent, additional resources may help to bring those agencies operating below performance expectations up to applicable standards. In recognition, however, of the possibility that some state agencies may not reach the desired performance standards, CMS should have the authority not to utilize a state survey or state board in a given state to respond to beneficiary complaints. CMS could keep this responsibility with the QIO or designate another entity to fulfill that role.

Remedies: QIOs have provided little in the way of remedies to beneficiaries complaining of poor quality care. SAs and state medical boards have a much greater range of remedies at their disposal. In addition, the alternative entity would provide an opportunity to expand remedies to complainants. In his testimony before the Senate Special Committee on Aging in 1999, Mike Hash, 
then Deputy Administrator of HCFA, stated that an essential element of a complaint process would be "interactions between complaint investigations and licensure and certification systems, the legal system, and facility-level grievance or continuous quality improvement processes."200 A more robust complaint system would provide compensation for individuals harmed as a result of poor quality health care. Additionally, it would provide beneficiaries with an opportunity to meet with providers; receive an apology and explanation of what happened; initiate an investigation of substandard care; and provide compensation to individuals harmed as a result of poor quality health care. Such a system, therefore, might incorporate elements of what has traditionally taken place in the courts through medical malpractice litigation. While this would be a revolutionary reform proposal, there are a number of reasons why it might make sense in this context. First, it would allow beneficiaries "one stop shopping." They could file a complaint and have all of their needs and interests met. Second, it would tie together the medical malpractice system and the quality improvement system in a way that has not been possible under the current "silo" based responses to poor quality care. ${ }^{201}$ The proposed reform would allow for an administratively-based compensation system rather than a trial-based system. The former could allow for an expert panel of reviewers to determine the appropriate level of compensation. Ideally, compensation levels would be tied to standards that would provide consistency across similar injuries. Criteria for damage payments could be "fault based" or could rely on a broader standard,

200. Hash, Hearing Testimony, supra note 117.

201. William Sage and Eleanor Kinney have proposed the idea of a Medicare led reform to the medical malpractice system. See William M. Sage \& Eleanor D. Kinney, A Malpractice System for Medicare, in MEDICAL MALPRACTICE REFORM IN THE UNITED STATES: NEW CENTURY, DIFFERENT ISSUES 318 (William M. Sage \& Rogan Kersh eds., 2006); Eleanor D. Kinney \& William M. Sage, Resolving Medical Malpractice Claims in the Medicare Program: Can It Be Done? 12 ConN. INS. L.J. 77, 77 (2005). To the extent that the reform proposal would focus on Medicare beneficiaries, Sage has provided a number of reasons for the approach. First, he argues that the conventional malpractice litigation process serves Medicare beneficiaries very poorly. Based on empirical data from Texas he asserts that "[e]lderly patients file fewer claims and receive lower payments when they do pursue legal action" than do younger patients. William M. Sage, The Role of Medicare in Medical Malpractice Reform, 9 J. HEALTH CARE L. \& POL'y 217, 221 (2006). He lists several explanations for this disparity:

Elderly patients tend not to realize that they have suffered negligent injuries. Even if they recognize a problem, seniors depend on their doctors and hospitals and often do not want to alienate them by filing a lawsuit. If elderly patients do seek redress, their lower remaining life expectancies and reduced employment rates are less likely to generate damages substantial enough to induce lawyers, who are often paid on contingency, to accept them as clients. Lawyers also know that it is difficult to settle cases involving elderly clients because causation of injury is seldom clear-cut in patients with pre-existing illnesses. Nor can elderly clients easily endure the long delays involved in litigation ....

Id. at 223-24. 
such as avoidable adverse events. Beneficiaries could choose whether to pursue the administrative system or the traditional tort system.

A final criterion that needs to be considered in this evaluation is the extent to which state survey agencies and state medical boards would be willing to take on this task. The directors of state survey agencies with whom we spoke seemed willing to take on this task, assuming it would be accompanied by additional resources. In fact, they seemed to think that it was inappropriate that QIOs were currently handling complaints. We are less certain of the willingness of state medical boards to take this on. Many boards are not part of the state's executive branch and operate independently or semi-independently. In addition, while state survey agencies already are partly federally funded and have federal obligations tied to this funding, state medical boards have little to do with federal agencies, except perhaps when dealing with Medicare fraud or DEA issues like drug diversion which requires working with state and federal prosecutors. CMS would likely need to contract with Boards to perform this function for additional funding. Through such a contract mechanism, CMS could specify a uniform complaint process with which the Boards would be obliged to comply. State medical boards, however, have been highly resistant to federalization (though more recently they have been undertaking some actions in coordination with federal agencies like cancer databases and model programs). Whether or not additional funding would be sufficient to entice boards to take on this role is unclear.

\section{CONCLUSION}

This paper explores the history of QIOs and their responsiveness to Medicare beneficiary complaints regarding the quality of their health care. Based on the recent IOM report recommendations that QIOs may not be the best home for this function, we explore an alternative entity that might take on this function. This alternative takes advantage of the significant experience and expertise of state survey agencies and state medical boards in responding to patient/consumer complaints about an individual or institutional health care provider. Neither the QIO nor the proposed alternative is an "ideal" process. Each has strengths and weaknesses. For example, QIOs have significant expertise when it comes to evaluating quality of care complaints; however, they have not been accessible to beneficiaries and often have not provided adequate explanations to beneficiaries about their investigation into allegations of poor quality care. Moreover, they have limited authority to implement corrective action and appear to be reluctant to use the authority they do have. As compared to state entities, QIOs have little experience responding to beneficiary complaints.

State survey agencies and state medical boards have significant experience responding to complaints and are very accessible to consumers and patients. They are perhaps "closer to the ground" when it comes to knowing what goes on in different institutions and in the medical community. On the other hand, 
in many cases they lack the resources to respond to complaints in a timely and thorough manner. While some state survey agencies have excellent systems in place to respond to complaints, including quality improvement systems, others are much less sophisticated in their operations. Recent efforts by CMS to monitor state agency performance in responding to complaints based on institutional care should improve state agency performance in responding to complaints across the board. The weak link in the alternative entity, however, is state medical boards, which lack CMS oversight and, in some states, operate independently of the executive branch. CMS could potentially overcome this weakness by contracting with state boards to participate in the complaint response process.

Although we did not evaluate the feasibility of an entirely new entity to handle beneficiary complaints, some of the pros and cons of a new entity are readily apparent. In comparison to the hybrid structure we propose, the new entity would be subject to CMS oversight and would likely be adequately funded upon its creation, at least for the first several years. Further, the entity would be focused wholly on Medicare complaints and would therefore, arguably, have a greater stake in seeking resolution of those complaints and the issues underlying them. In an atmosphere of limited health care dollars, however, it may be impractical to create a new entity that would duplicate the efforts of existing state organizations that are currently charged with complaint investigation and resolution. 
Appendix $\mathbf{A}^{202}$

\begin{tabular}{|c|c|}
\hline Element & $\begin{array}{l}\text { Characteristics of an } \\
\text { Effective Complaint } \\
\text { Process }\end{array}$ \\
\hline 1. Accessibility & $\begin{array}{l}\text { Complainants are aware of the } \\
\text { system and find it easy to use. }\end{array}$ \\
\hline 2. Investigative capacity & $\begin{array}{l}\text { Appropriate experts, resources, } \\
\text { and methods are available to assess } \\
\text { complaints and determine if they are } \\
\text { part of an underlying pattern. }\end{array}$ \\
\hline $\begin{array}{l}\text { 3. Interventions and fol- } \\
\text { low-through }\end{array}$ & $\begin{array}{l}\text { Substantiated complaints result in } \\
\text { appropriate corrective action. Monitor- } \\
\text { ing assures compliance. }\end{array}$ \\
\hline $\begin{array}{l}\text { 4. Quality improvement } \\
\text { orientation }\end{array}$ & $\begin{array}{l}\text { Complaints guide quality im- } \\
\text { provement efforts. }\end{array}$ \\
\hline 5. Responsiveness & $\begin{array}{l}\text { Responses to complainants are } \\
\text { regular, substantive, and clear. }\end{array}$ \\
\hline 6. Timeliness & $\begin{array}{l}\text { Each step is completed within an } \\
\text { established, reasonable time frame, and } \\
\text { mechanisms exist to deal with emer- } \\
\text { gent complaints in an expedited man- } \\
\text { ner. }\end{array}$ \\
\hline 7. Objectivity & $\begin{array}{l}\text { The review process is unbiased, } \\
\text { balancing the rights of each party. }\end{array}$ \\
\hline 8. Public accountability & $\begin{array}{l}\text { Complaint information is made } \\
\text { available to the public. }\end{array}$ \\
\hline
\end{tabular}

202. 2001 OIG REPORT, supra note 2 , at 6. 
